\title{
WestVirginiaUniversity
}

THE RESEARCH REPOSITORY @ WVU

Graduate Theses, Dissertations, and Problem Reports

2008

\section{Effects of induced acute phase response in ewes on early embryo survival}

Tina Lynn Dow

West Virginia University

Follow this and additional works at: https://researchrepository.wvu.edu/etd

\section{Recommended Citation}

Dow, Tina Lynn, "Effects of induced acute phase response in ewes on early embryo survival" (2008). Graduate Theses, Dissertations, and Problem Reports. 4366.

https://researchrepository.wvu.edu/etd/4366

This Thesis is protected by copyright and/or related rights. It has been brought to you by the The Research Repository @ WVU with permission from the rights-holder(s). You are free to use this Thesis in any way that is permitted by the copyright and related rights legislation that applies to your use. For other uses you must obtain permission from the rights-holder(s) directly, unless additional rights are indicated by a Creative Commons license in the record and/ or on the work itself. This Thesis has been accepted for inclusion in WVU Graduate Theses, Dissertations, and Problem Reports collection by an authorized administrator of The Research Repository @ WVU. For more information, please contact researchrepository@mail.wvu.edu. 
Effects of Induced Acute Phase Response in Ewes on Early Embryo Survival

\title{
Tina Lynn Dow
}

Thesis submitted to the

\author{
Davis College of Agriculture, Forestry, and Consumer Sciences \\ at West Virginia University \\ in Partial Fulfillment of the Requirements \\ for the Degree of
}

\author{
Master of Science \\ in \\ Reproductive Physiology
}

Robert A. Dailey, Ph.D., Chair

Theodore H. Elsasser, Ph.D.

Jorge A. Flores, Ph.D.

Division of Animal and Nutritional Sciences

Morgantown, West Virginia

2008

Keywords: Early Embryonic Loss, Peptidoglycan-Polysaccharide, Acute

Phase Response, Sheep, Inflammation 


\section{Abstract \\ Effects of Induced Acute Phase Response in Ewes on Early Embryo Survival}

Tina Lynn Dow

Early pregnant ewes, 5/6 day post coitus (dpc) were used as a model to study early embryonic loss via gram-positive bacterial infections, such as mastitis. Ewes 5/6 dpc were injected with a gram-positive bacteria cell wall component, peptidoglycanpolysaccharide (PG-PS), to induce an innate immune system acute phase response (APR). The induction of the APR and its reactant molecules, such as cytokines and acute phase proteins (APP), were initiated to study their effects on embryonic loss. Twenty Suffolk ewes were synchronized for estrus and bred by fertile rams. At 4 dpc ewes were anesthetized and catheters were surgically placed in the right rear leg in the caudal vena cava via saphenous vein, as well as in the jugular. Ewes were randomly assigned to treatment groups on $5 \mathrm{dpc}$, and received either a $60 \mu \mathrm{g} / \mathrm{kg}$ BW dose of PG-PS (n=10) or a sham injection of $0.9 \% \mathrm{NaCl}(n=10)$ i.v. in the jugular vein contralateral of the catheter. Plasma was collected from jugular and caudal vena cava via the saphenous vein before challenge, followed by post challenge samples every 15 minutes until 2 hours, every hour until 12 hours, and once at 24, 36, and 48 hours. Assays were conducted for APR reactants tumor necrosis factor- $\alpha$ (TNF- $\alpha)$, serum amyloid A (SAA), and haptoglobin $(\mathrm{Hp})$, as well as the pregnancy maintenance hormone, progesterone $\left(\mathrm{P}_{4}\right)$. In addition, behavior changes and body temperature were also documented before PG-PS injection followed by every hour for 12 hours and then again at 24, 36, and 48 post challenge. Concentrations of TNF- $\alpha$ and $\mathrm{P}_{4}$ were quantified using radioimmunoassay, whereas ELISA was used to measure SAA and HP concentrations. Intoxication of day 5/6 pregnant ewes with $60 \mu \mathrm{g} / \mathrm{kg}$ BW PG-PS induced significant differences in TNF- $\alpha$ concentration between sample sites $(\mathrm{p}<0.001)$ and treatment groups $(\mathrm{p}<0.02)$. SAA and $\mathrm{Hp}$ concentrations increased significantly $(\mathrm{p}<0.0001)$ in challenged ewes. Fever, loss of appetite, lethargy, and vaginal discharge were documented in all treated ewes, as well as $100 \%$ embryonic loss by $21 \mathrm{dpc}$. Data from this experiment demonstrate that injection of PG-PS systemically leads to production of APP and behavioral changes characteristic of an APR. 


\section{Table of Contents}

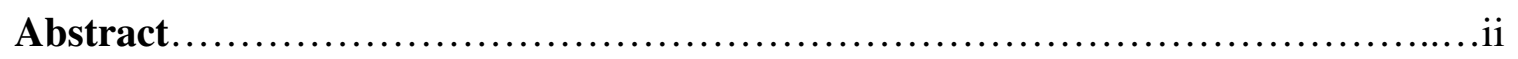

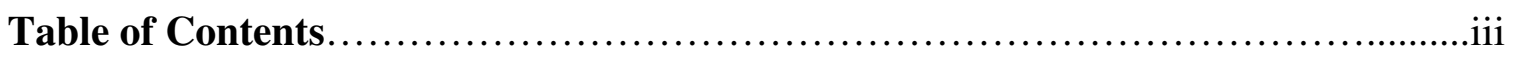

List of Tables.................................................................

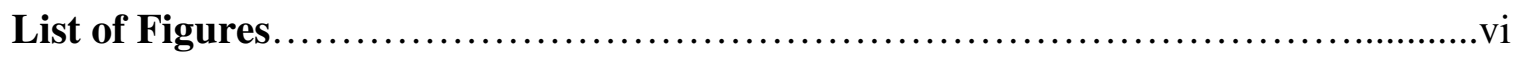

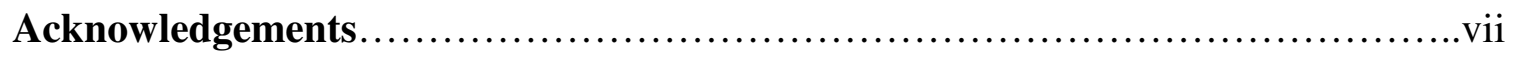

Literature Review......................................................

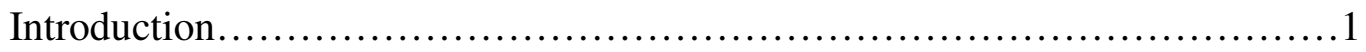

Reproduction Cycle.................................................. 3

Estrous Cycle in the Ewe........................................... 3

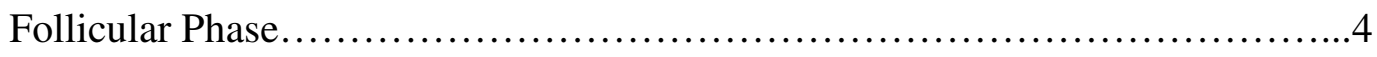

Luteal Phase ........................................................ 5

Early Pregnancy...................................................

Embryogenesis.................................................. 9

Maternal Recognition of Pregnancy .................................... 12

Bacteria.......................................................... 13

Innate Immunity................................................ 16

Adaptive/Acquired Immunity.........................................24

Humoral..................................................25

MHC I and II Molecules.........................................25

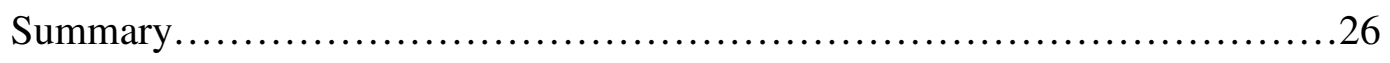

Innate and Acquired/Adaptive Immune Response Summary...........27

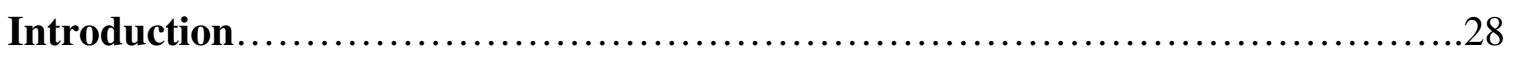


Materials and Methods.................................................. 31

Synchronization Protocol for Ewes........................................31

Saphenous Vein Catheter Construction and Placement (4 dpc)................31

PG-PS Preparation, Treatment Assignments, Blood Collection (5/6 dpc)............32

Assays................................................................ 33

Statistical Analysis...................................................... 34

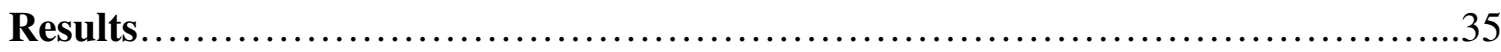

Plasma Progesterone Concentrations at 14 and $21 \mathrm{dpc}$ in Jugular Blood, Mean

Body Temperatures, Vaginal Discharge and Ultrasonography Results in Suffolk

Ewes....................................................................

Concentrations of TNF- $\alpha$ in Caudal Vena Cava and Jugular Blood Plasma in

Suffolk Ewes.................................................... 38

Concentrations of TNF- $\alpha$ in PG-PS Treated Suffolk Ewes.......................39

Concentrations of Serum Amyloid A in Suffolk Ewes..........................40

Concentrations of Haptoglobin in Suffolk Ewes...........................41

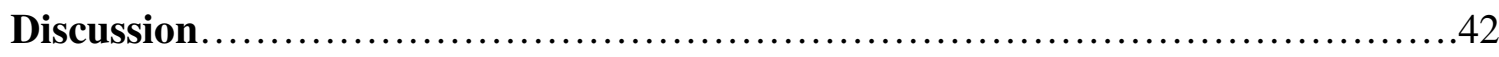

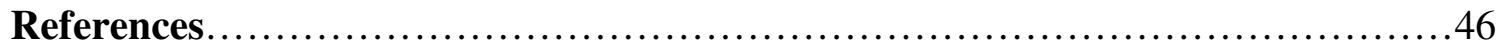

Approval of the Examining Committee........................................69 


\section{List of Tables}

Table 1. Plasma Progesterone Concentrations in Jugular Blood at 14 and $21 \mathrm{dpc}$, Mean

Body Temperatures, Vaginal Discharge and Ultrasonography Results in Suffolk

Ewes......................................................................... 37 


\section{List of Figures}

Figure 1. Innate and Adaptive Immunity Summary Diagram.......................27

Figure 2. Concentrations of TNF- $\alpha$ from Caudal Vena Cava and Jugular Vein in Suffolk

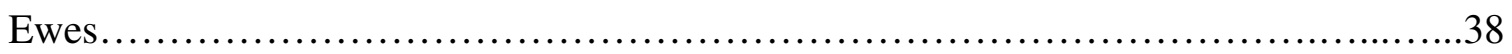

Figure 3. Concentrations of TNF- $\alpha$ from Caudal Vena Cava in PG-PS Treated Suffolk

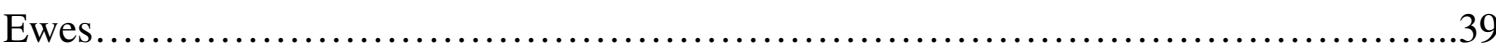

Figure 4. Jugular Concentrations of Serum Amyloid A in Suffolk

Ewes......................................................................... 40

Figure 5. Jugular Concentrations of Haptoglobin in Suffolk

Ewes........................................................................ 41 


\section{$\underline{\text { Acknowledgements }}$}

I would like to thank my committee members Dr. Dailey, Dr. Elsasser, and Dr. Flores for their time, wisdom, and patience. Thank you to Dr. Inskeep for his instruction and vast amounts of knowledge, I will forever be grateful. Additionally, I would like to thank all of my fellow graduate students for their moral support and help during my project, as well as the undergraduates that sacrificed weekends and sleep to help collect blood samples at all hours of the night. On a more personal note, I would like to thank my very good friends Jennifer Warmbold, Ginny, Alice and Kate who continue to be my driving force, and my hero Steve, who is gone, but never forgotten. I thank Brian Eberly

for his friendship and constructive criticism that at times was much needed. Most of all, I thank my husband, Andrew Dow, who has given me the courage to face whatever may come my way. You have been around the world with me and back again, and it is just the beginning. Thank you for your love, honesty and friendship, in addition to your patience with me no matter how many times I have asked you the formula for volume. 


\section{Introduction}

The embryo's ability to biochemically communicate with the uterus is crucial for continuation of pregnancy. A viable conceptus must signal to maintain the life of the corpus luteum (CL), and, immunologically speaking, prevent the mother from rejecting the semi-allogenic fetus. The mechanism, termed maternal recognition of pregnancy, involves structural, hormonal and genetic changes in both the mother and embryo (Paria et al., 2001). Overall, these changes ensure that progesterone $\left(\mathrm{P}_{4}\right)$, the hormone secreted by the CL that maintains pregnancy, is continually produced, as a result the preimplanted embryo is nourished, and the uterus becomes prepared for the conceptus to implant, which causes the start of placentation followed by the placental production of $\mathrm{P}_{4}$ (Senger, 2003).

For a variety of domestic mammals, receptivity to a male, ovulation and fertilization are proficient processes. However, early embryonic losses are relatively high; losses in swine have been estimated to be $25-30 \%$ (Moore et al., 2005), whereas humans experience $\sim 35 \%$ loss (Wang et al., 2003), and cattle and sheep lose up to 3035\% (Hansen and Soto, 2004). Shahani and colleagues (1992) observed that in the mouse $\sim 75 \%$ of embryonic loss takes place within the first six days of gestation. In addition to bringing death to the embryo, early embryonic loss has negative effects on the dam, as well as a significant economic impact on animal agriculture (Lucy et al., 2004; Moore et al., 2005). Estimates suggest that a reduction in embryonic loss by just $2.8 \%$ would result in the additional production of 135 thousand sheep, 1 million beef cattle, 3.2 million pigs, and 3.5 million gallons of milk per year (Senger, 2003). Many factors interact to cause early embryonic loss, in addition to genetic abnormalities of the 
conceptus that restrict growth and development. In sheep, cattle and pigs, embryos undergo a period of growth wherein they change from a spherical form to one which is more tubular and then filamentous prior to implantation. During this time, day 13-21 of gestation, the embryo begins to produce a cytokine, interferon-tau (IFN- $\tau$ ), the signal for maternal recognition of pregnancy (Spencer et al., 2004). Embryos that are developmentally delayed are unable to produce IFN- $\tau$ at the correct time or in appropriate concentrations. Moreover, the lack of the maternal signal results in endometrial production of prostaglandin $\mathrm{F}_{2} \alpha\left(\mathrm{PGF}_{2} \alpha\right)$ and ultimately luteolysis.

External environmental factors including nutrition, weather, and disease also affect early embryonic loss. Reproductive efficiency is impacted by stressors such as heat or cold extremes, poor diet, as well as pathogenic living conditions (Hansen, 2007). Research involving heat stressors on embryonic survival in sheep carried out by Dutt in 1963 demonstrated the conceptus was extremely vulnerable to detrimental effects initiated by a significant increase in maternal body temperature between days 0 and 4 of gestation. However, from approximately day 6 of gestation, an embryonic heat tolerance developed allowing the embryo to be less susceptible to inflammatory factors such as cytokines, as well as other hypothalamic-pituitary-adrenal and hypothalamic-pituitaryovarian disturbances that could result in a decline in embryonic survival.

Bacterial infections have detrimental effects on the survival of the developing conceptus. For example, mastitis, an inflammatory disease of the mammary gland, disrupts reproduction in dairy cattle. Barker and colleagues in 1998 observed a decrease in conception rate if mastitis occurred before the first insemination, and that more inseminations were required to establish pregnancy if cows were infected with mastitis 
after first insemination. Either situation resulted in a longer interval between calving and pregnancy. Furthermore, mated ewes inoculated with either peptidoglycan-

polysaccharide, a gram-positive bacterial cell wall component, or killed Streptococcus pyogenes to mimic the effects of mastitis increased early embryonic loss (Stewart et al., 2003; Holásková et al., 2004). Therefore, the early immune response, i.e., inflammation, associated with diseases such as bacterial derived mastitis likely compromise embryonic survival (Soto et al., 2003; Hansen et al., 2004).

\section{Reproduction Cycle}

Reproduction is manifested as a cycle of events that begin when the female is sexually receptive (termed estrus in non-primate mammals) and continues through pregnancy and parturition, at which time the series is repeated. The interval from one estrus to another is designated as an estrous cycle, and its length is determined by endocrine interactions within the hypothalamo-pituitary-ovarian axis, as influenced by uterine secretions in most species. Although the hypothalmo-pituitary-ovarian axis controls ovulation via stimulation of localized hormonal secretions in the reproductive tract, for sheep and cattle the estrous cycle is uterine-dependent (Land et al., 1976). In work reviewed by Bazer in 1998, hysterectomy during the estrous cycle in both cattle and sheep resulted in the lifespan of the CL being extended. Therefore, the uterus is the source of $\mathrm{PGF}_{2 \alpha}$, the luteolysin. Because hysterectomy did not result in an extended lifespan of the CL in primates, the menstrual cycle is uterine-independent (Bazer, 1998).

\section{Estrous Cycle in the Ewe}

Ewes are seasonally polyestrous with lengths of estrous cycles averaging 17 days. Because their estrous cycles begin in the late summer or early fall and continue through 
early spring, ewes are classified as short day breeders. Seasonal breeding patterns are vital for neonatal survival, as ewes conceive in the late fall to early winter and lamb in the early spring when weather conditions are more optimal and food is readily available.

Gonadatropin-releasing hormone $(\mathrm{GnRH})$, a decapeptide secreted by the hypothalamus in a pulsatile fashion, stimulates the release of two glycoprotein hormones, follicle stimulating hormone (FSH) and lutinizing hormone ( $\mathrm{LH})$, from the anterior pituitary gland. Each enters the systemic circulation and travels to its target site on the ovary prompting follicular development, ovulation, and formation of the CL. Because FSH and LH exert distinct effects on the ovary, the estrous cycle can be divided into two phases, the follicular phase and the luteal phase (Senger, 2003).

\section{Follicular Phase}

The follicular phase of the estrous cycle is named because the principal structure and hormonal target on the ovary at this time is the follicle(s). The follicular phase consists of two periods: proestrus and estrus. Proestrus begins after the CL from the previous estrous cycle has regressed. The second part of the follicular phase is characterized by estrus and ovulation.

During the follicular phase, follicular growth is accompanied by secretion of estradiol $\left(E_{2}\right)$ by the follicles. An increase in systemic concentrations of $E_{2}$ brings about female receptivity to the male, uterine gland growth and increased mucus secretions in the cervix and vagina. $\mathrm{E}_{2}$ has a positive feedback upon the hypothalamic preovulatory surge center to stimulate secretion of GnRH that is both high in frequency and amplitude. The surge in GnRH secretion subsequently stimulates a surge in $\mathrm{LH}$ from the anterior pituitary that results in ovulation (Baird and McNeilly, 1981). 
Ovulation is the end result of collaboratory effects of increases in follicular vascularization, smooth muscle contractions via prostaglandin synthesis, and collagenase activity on the follicular wall (Krishna et al., 1986; Murdoch et al., 1986). For the ovid, estrus can last 18-48 hours, with ovulation beginning at about 24-30 hours. The ovulated follicle undergoes both cellular and structural changes to form the CL, which is the main ovarian structure in the luteal phase.

\section{Luteal Phase}

The luteal phase which constitutes $80 \%$ of the estrous cycle, beginning after ovulation and continues until the CL regresses in the absence of pregnancy, is subdivided into two parts: metestrus and diestrus. Due to the rupture of small blood vessels during ovulation, blood clots are formed in the ovulating follicle which is then termed a corpus hemorrhagicum $(\mathrm{CH})$, a transition structure leading to the formation of the $\mathrm{CL}$, an endocrine gland (Bazer, 1998). After ovulation, cells from the theca interna and the granulosa form small (theca) and large (granulosa) luteal cells (Hoyer and Niswender, 1985). Complete lutenization occurs at metestrus, which in sheep lasts approximately 45 days and is characterized by low systemic concentrations of $\mathrm{E}_{2}$ as well as $\mathrm{P}_{4}$. At day 10 to 14 , the CL reaches its maximum size and function. If an embryo is not present $\mathrm{P}_{4}$ concentrations will decrease with the regression of the CL (Senger, 2003).

Depending on the presence or absence of a conceptus, $\mathrm{P}_{4}$ will act upon multiple reaction sites within the hypothalamo-pituitary-ovarian axis, along with uterine and mammary targets (Chappell et al., 1997; Scott et al., 2000; Meikle et al., 2004). In the hypothalamus, $\mathrm{P}_{4}$ inhibits GnRH secretion and suppresses secretion of FSH and LH from the pituitary. As $E_{2}$ concentrations are low, behaviors associated with high $E_{2}$, such as 
estrus, are suppressed as well. In addition, $\mathrm{P}_{4}$ directly affects physiological changes of the uterine endometrium to provide an optimal environment for a developing embryo (Bazer and First, 1983; Spencer, 2002). $\mathrm{P}_{4}$ stimulates the production of secretory proteins, which, in turn, aid in the differentiation and glandular remodeling of the uterine tissue, directly causing the production of histotroph (Roberts and Bazer, 1988). In most domestic livestock species ovulation is spontaneous and regression of the $\mathrm{CL}$ is a uterinedependent process. As McCracken and colleagues in 1972 observed, the uterine endometrium is the main source for $\mathrm{PGF}_{2 \alpha}$, which is transported to the ovary via a counter current exchange mechanism of the uterine vein and ovarian artery. At the ovary, $\mathrm{PGF}_{2 \alpha}$ exerts its effects on the $\mathrm{CL}$ and stimulates regression of the $\mathrm{CL}$ and a decrease in $\mathrm{P}_{4}$ concentrations. Additionally, the $\mathrm{CL}$ itself also secretes $\mathrm{PGF}_{2} \alpha$.

Luteolysis is characterized as both a change in function and structure of the CL. As the $\mathrm{CL}$ regresses plasma concentrations of $\mathrm{P}_{4}$ fall almost immediately, resulting in luteal cell death (Hoyer, 1998). Working with ewes, McGuire et al. (1994) showed that administering $\mathrm{PGF}_{2 \alpha}$ would result in decreased concentrations of systemic $\mathrm{P}_{4}$ within 5 hours, with luteal cell death following after $\sim 12$ hours. The regression of the CL is the keystone event that characterizes the end of the luteal phase. However, if there is a viable conceptus, the lifespan of the CL will be prolonged. The conceptus will produce antiluteolytic signals that inhibit the production of $\mathrm{PGF}_{2 \alpha}$ as well as alert the female that it is in the reproductive tract and that it should be under immune system protection; the process is referred to as the maternal recognition of pregnancy (Bazer, 1998). 


\section{Early Pregnancy}

Upon copulation and intromission, the male deposits an ejaculate rich with uncapacitated sperm and seminal plasma. The volume of the ejaculate and the site of deposition is species specific. Once in the female reproductive tract, the semen is immediately moved via uterine contractions and watery mucous secretions upward into the cervix, passing through the uterine horn eventually reaching the ampula/isthmus junction, the site of fertilization, in the oviduct. Simultaneously, the sperm goes through a maturation process termed capacitation in which enzymes in the female tract act to remove adherent seminal plasma proteins, as well as works to reorganize sperm plasma membrane lipids and proteins (Senger, 2003). In addition, influxes of extracellular calcium, increase in cyclic AMP, and a decrease in intracellular $\mathrm{pH}$ promote hyperactivity of the sperm. This period of increased motility of the sperm both aids in propelling the sperm to the egg and in driving it through the outermost egg coat, the zona pellucida (Dean, 1992).

The binding of sperm to the zona pellucida, is a receptor-ligand interaction with a high degree of specificity. Glycoproteins on the zona pellucida function as sperm receptors. Almeida et al., (1995) observed that there are several proteins on the surface of the sperm that bind to the zona pellucida carbohydrate receptors. The constant propulsive force from the sperm's flagellating tail, in combination with acrosomal enzymes, allows the sperm to create a tract through the zona pellucida. These two factors, motility- and zona-digesting enzymes, allow the sperm to traverse the zona pellucida. Some investigators believe that sperm motility is of overriding importance to zona penetration, allowing the knife-shaped mammalian sperm to basically cut its way through the zona 
pellucida at the same time acrosomal enzymes are digesting the zona (Allen and Green, 1997). Once a sperm penetrates the zona pellucida, it binds to and fuses with the plasma membrane of the oocyte at the posterior (post-acrosomal) region of the sperm head (Denker, 2000).

Prior to fertilization, the egg is quiescent, arrested in metaphase of the second meiotic division. Upon binding of a sperm, the egg rapidly undergoes a number of metabolic and physical changes that collectively are called egg activation. Prominent effects include a rise in the intracellular concentration of calcium, completion of the second meiotic division and the cortical reaction, massive exocytosis of cortical granules seen shortly after sperm-oocyte fusion. Cortical granules contain a mixture of enzymes, including several proteases, which diffuse into the zona pellucida and alter its structure, inducing what is known as the zona reaction. Components of cortical granules may also interact with the oocyte plasma membrane (Wasserman, 1990; Yanagimachi, 1996).

As Denker (2000) reported, the critical importance of the zona reaction is that it represents the major block to polyspermy in most mammals. Polyspermy is the entrance into the egg by more than one sperm resulting in a nonviable zygote. This block is the result of two measurable changes induced in the zona pellucida: the zona pellucida hardens, and the sperm receptors in the zona pellucida are destroyed (Dunbar, 1991). The loss of sperm receptors can be demonstrated by mixing sperm with both unfertilized oocytes (which have not yet undergone the zona reaction) and two-cell embryos (which have previously undergone cortical and zona reactions). Whereby, sperm attach avidly to the zona pellucida of oocytes, but fail to bind to the two-cell embryos (Glabe and Vacquier, 1978). 
Following fusion of the fertilizing sperm with the oocyte, the sperm head is incorporated into the egg cytoplasm. The nuclear envelope of the sperm disperses, and the chromatin rapidly loosens from its tightly packed state in a process called decondensation. In vertebrates, other sperm components, including mitochondria, are degraded rather than incorporated into the embryo. Chromatin from both the sperm and egg are soon encapsulated in a nuclear membrane, forming pronuclei. Each pronucleus contains a haploid genome until their membranes break down, and the two genomes condense into chromosomes, thereby reconstituting a diploid organism (Gilbert, 2006).

\section{$\underline{\text { Embryogenesis }}$}

Once fertilization is accomplished, the resulting structure is called the zygote. The zygote undergoes rapid cell division with no significant growth (cleavage) and is initiated approximately 24-30 hours after fertilization (Wong and Adashi, 2006). The dividing cells of the zygote are called blastomeres and become smaller in size with each successful cell division as the size is constrained by the presence of the zona pellucida. It is important to note that it is the maternal mRNA that controls the first cleavage divisions, with the embryonic genome becoming activated at the 2-cell stage in the mouse and golden hamster (Seshagiri et al., 1992), the 4- to 8- cell stage in the human (Hardy and Spanos, 2002), and the 8-cell stage in swine, cattle and sheep (Crosby et al., 1988). When the embryo has reached the 16-cell stage, the blastomeres become more tightly compact forming gaps and tight junctions. The compaction process marks the beginning of the embryonic cell differentiation where a separation of cells forming an inner and outer cell masses occurs. This new formation of blastomeres, termed the morula, is now ready to leave the site of fertilization and enter into the uterus on day 3 in the human and 
the mouse (Hardy and Spanos, 2002), and day 4 in sheep and cattle (Rowson and Moor, 1966).

At the 32-cell stage of embryonic development, a fluid-filled cavity begins to appear marking another developmental milestone from morula to blastocyst. With the formation of the blastocyst there is a clear distinction of the pluripotent inner cell mass which will become the embryo proper, and the outer cell mass or trophectoderm that will transition into the extra-embryonic membranes. The trophectoderm cells will make the first physical and physiological contact with the maternal uterine luminal epithelium and initiate attachment (Paria et al., 2001). At the blastocyst stage, the conceptus is still enveloped by the zona pellucida, which adds to the structural integrity, but must be shed to allow for the continuation of development and attachment. Although the zona pellucida becomes hardened after the invasion of the ovum by the sperm, it is not impenetrable (Hastings et al., 1972; Sinowatz et al., 2001). In 2007, Loureiro and colleagues observed that during times of heat stress or innate immune challenges resulting in the secretion of the proinflammatory cytokine tumor necrosis factor- $\alpha$ (TNF$\alpha$ ), the zona pellucida alone is unable to protect the embryo from apoptosis. Hansen (2007) found that there is a decrease in vulnerability to environmental stresses for the embryo as it ages and develops. This decreased susceptibility to detrimental effects on the embryo is yet to be defined, but it could be that as the embryonic genome is completely turned on, the embryo gains the protection of a very early innate immune system.

After hatching of the blastocyst from its zona pellucida, on day 8 of gestation in the sheep, the embryo becomes free floating and moves through an ever changing fluid 
environment, lacking a blood supply, and without direct cell to cell contact with the reproductive tract (Böving, 1959). During this time the embryo continues to develop and differentiate, gaining its nourishment from uterine secretions called histotroph. The embryo's cellular activities including cell division, gene expression, and metabolic processes are directly influenced by the uterine environment, regulated by locally produced growth factors. Continued blastocyst development and differentiation, attachment, recognition and maintenance of pregnancy require an effective maternalembryonic dialogue mediated by these same growth factors. By day 16 of pregnancy in the sheep the initiation of attachment has begun (Böving, 1959; Boshier, 1969).

There are many criteria that have to be met in order for attachment to occur. The "window of opportunity" for uterine receptivity is defined as the limited time by which the uterine environment is optimal for the receiving embryo to adhere to the uterine luminal epithelium. Prior to implantation the blastocyst becomes situated in close proximity with the uterine epithelium allowing for cross-talk to occur followed by the very first connection between the conceptus and the endometrium referred to as apposition. In ruminants, apposition is restricted to uterine epithelial glandular sites called aglandular caruncular and glandular intercaruncular tissues which will be the superficial sites of attachment and placentation (Wimsatt, 1950; Senger, 2003). As Lefèvre and Boulay (1993) demonstrated in the pig, uterine differentiation at the time of apposition, adhesion, and implantation is coordinated maternally by an increase in vascular permeability and the secretion of $\mathrm{P}_{4}$ and estrogen in a spatiotemporal manner, and embryonically by production of IFN- $\tau$. 


\section{Maternal Recognition of Pregnancy}

The communication between the female and the developing embryo to ensure survival of the conceptus through prolonging the life of the CL and resulting establishment of pregnancy can be defined as maternal recognition of pregnancy. At day 13-20 of gestation in domestic livestock species, the developing embryo begins to produce INF- $\tau$, an anti-luteolytic hormone that blocks uterine $\mathrm{PGF}_{2 \alpha}$ production thereby prolonging the life of the CL. Synchrony between the conceptus and the uterus is essential, as well as optimal physiological conditions that will allow acceptance of each other (Roberts et al., 1996). The process of maternal recognition of pregnancy is a species specific event: in species such as humans, swine, sheep and cattle the embryo provides the recognition signals via the production of hormonal signals such as human chorionic gonadatropin (hCG), $\mathrm{E}_{2}$ and IFN- $\tau$ respectively. As Bazer and Thatcher observed (1977) the embryo in swine produces $\mathrm{E}_{2}$, as well as stimulates uterine secretions of $\mathrm{PGF}_{2 \alpha}$ causes an extension of the lifespan of the CL. However, in the human being, hCG is secreted from the trophoblast cells of the developing embryo and takes a direct action by stimulating a continual secretion of $\mathrm{P}_{4}$ by the CL. In comparison, IFN- $\tau$ in ruminants indirectly affects the $\mathrm{CL}$ by inhibiting endometrial secretion of $\mathrm{PGF}_{2 \alpha}$ (Bazer, 1998). Regardless the origin of the signal, the main objective of embryonic/uterine dialogue is to ensure the lifespan of the CL is prolonged, which in turn continues its secretion of $\mathrm{P}_{4}$.

In cattle and sheep, IFN- $\tau$ is an anti-luteolytic that acts on the endometrium in a paracrine fashion to inhibit the pulses of $\mathrm{PGF}_{2 \alpha}$ induced by oxytocin. In addition to being a signal for maternal recognition of pregnancy, IFN- $\tau$ also has antiviral, 
antiproliferative, and immunomodulatory properties. In the ewe, mononuclear trophectoderm cells in the embryo synthesize and secrete IFN- $\tau$ between day 10 and 21 of gestation, with a maximal production on day 14-15. On day 10 the embryo begins elongating from a spherical shape to a more filamentous one as it initiates production of IFN- $\tau$ (Spencer et al., 2004). Spencer and colleagues (1996) observed an increase in IFN- $\tau$ secretion (ng/uterine flushing) for spherical to tubular to filamentous growth, resulting in 312ng, 1380ng, and 4455ng, respectively.

Much research has been directed towards delineating the mechanism by which IFN- $\tau$ inhibits luteolysis. Spencer and Bazer (1995) found that the anti-luteolytic effect of IFN- $\tau$ is a result of suppression of estrogen and oxytocin receptors in the endometrium. Indirectly, IFN- $\tau$ inhibits estrogen receptor gene transcription thereby precluding oxytocin receptor expression by estrogen and oxytocin receptors in the endometrium, which consequently diminished peak frequency and amplitude of endometrial $\mathrm{PGF}_{2 \alpha}$ secretion (Spencer and Bazer, 1995; Fleming et al., 2001, 2006).

\section{$\underline{\text { Bacteria }}$}

Bacteria consist of mycoplasms, cyanobacteria, gram-positive bacteria, and gramnegative bacteria, and with a few exceptions, bacterial cell walls composed of peptidoglycan. Peptidoglycan, also called murein, is a large polymer consisting of interlocking chains of identical peptidoglycan monomers. Each peptidoglycan monomer is made up of two joined amino sugars, $\mathrm{N}$-acetylmuramic acid (NAM) and Nacetylglucosamine (NAG), with a polypeptide attached to the NAM. Peptidoglycan monomers are joined by the enzyme transglycosidase and held together via glycosidic bonds. Once polymers have been formed, peptide cross-linkages protruding from the 
NAM molecules hold the peptide together with help from transpeptidase. This side-byside and layered bonding gives the cell wall strength and semi-rigidity. Peptidoglycan, or its fragments, can induce a multitude of biological effects such as inflammation, fever lethargy, decreased appetite, and enhanced immune responses (Royet and Dziarski, 2007).

Bacteria are classified as gram-positive or gram-negative based on the percentage of peptidoglycan in its cell wall. The cell wall of gram-positive bacteria consists of 60-80 $\%$ peptidoglycan, whereas the peptidoglycan content of the gram-negative bacteria is 10$20 \%$ (Royet and Dziarski, 2007). The outer surface of the peptidoglycan is studded with proteins specific to the particular strain and species of bacteria it is present on, thus it serves as a biomarker that alerts the innate immune system of the host cell to its presence. Along with lipoteichonic acid (LTA), peptidoglycan not only increases the structural integrity and strength of the cell wall, but is important in the prevention of osmotic lysis, the mechanism of action of some antibiotics. Peptidoglycan is not the only constituent in the bacterial cell wall. Kengatharan et al., (1998) showed that peptidoglycan by itself has no effects on eliciting a response by a host organism's innate immunity. However, when combined with LTA, peptidoglycan can initiate an immune response by activating leukocytes and stimulating the generation of proinflammatory cytokines. Because of the synergistic effects of peptidoglycan and LTA, collectively they are referred to as the peptidoglycan-polysaccharide complex (Tizzard, 2004).

Infections from gram-positive bacteria like bacillus, listeria, streptococcus, and staphylococcus, which have been linked to mastitis, cause detrimental health effects and even death. Economic losses for the dairy industry alone are estimated at well past $\$ 2$ 
billion dollars (Stevenson, 2001). In addition to the loss from discarded milk, mammary infections initiate immune responses that possibly have ramifications in early embryo loss and death of the dam (Morris et al., 2002).

A bacterium has its own innate defense mechanism that is species and strain specific. The carotenoid pigments that give Staphylococcus aureus, a major contributing bacterium to mastitis, its golden color and group B streptococci (GBS) its orange tint, actually cause a shield like effect against the toxic oxidants produced by neutrophils that are used to kill bacteria. In addition, some bacteria, such as Staphylococcus aureus and Streptococcus pyogenes themselves produce a powerful endotoxin called leukocidin, which causes damage to the cytoplasmic membrane of the phagocyte or lysosome of the host. This membrane attack results in the phagocyte being killed by its own enzymes. There are also bacterial actions which prevent the formation of a membrane attack complex (MAC). Shigella and Salmonella can initiate macrophage apoptosis, as well as produce its own protein that binds to a portion of the antibody allowing the bacteria to become coated with antibodies in a way that it does not result in opsonization, thereby evading the innate immune system (Todar, 2002).

A unique part of bacteria pathogenicity is the production of virulence factors that damage the host. To not only cause disease, but also damage, bacteria must be able to maintain a reservoir before and after infection, leave the reservoir to gain access to the new host, and colonize the body. Another such virulent factor includes the ability of the bacteria to produce pathogen-associated molecular pattern (PAMP) that bind to host defense cells causing them to synthesize and secrete proinflammatory cytokines and chemokines. Although this secretion of cytokines and chemokines are helpful to the 
immune system of the host, it is still a process that results in tissue damage, and at high concentrations host death. Exotoxins are protein toxins that are either released from living bacteria or upon bacterial lysis. Exotoxins can serve as superantigens, causing severe damage to host cell membranes (Wilson et al., 2002).

\section{Innate Immunity}

Innate immunity refers to the host defense mechanism that all living creatures are born with and is the initial response by the body to eliminate any pathogenic molecule (antigen-nonspecific) and prevent infection. This host immunity is used immediately upon recognition of a foreign invader and is fully activated within several hours after exposure (Wira et al., 2005). Even though innate immunity is antigen-nonspecific, defense cells such as macrophages, neutrophils and monocytes do recognize a few highly conserved structures present on a variety of different microorganisms. These conserved structures or PAMP such as lipopolysaccharide (LPS), peptidoglycan, LTA, mannose, bacterial DNA and glucans are all that is required to initiate the correct cascade and begin the host immune attack (Janeway and Medzhitov, 2002).

In order to protect against infection, the host organism must be able to recognize self from non-self by identifying molecules that are species and strain specific for a particular type of pathogen, as well as those molecules that are found within the host PAMP (Janeway and Medzhitov 2002). Pattern-recognition receptors (PRR) of defense cells bind PAMP, peptidoglycan and teichoic acid, triggering innate immune responses (fever, inflammation and phagocytosis) and activate the complement and lectin defense pathways. In all, the innate immune system is thought to be able to recognize $10^{3}$ molecular patterns (Tizzard, 2004). Additionally, defense cells within a host, like 
macrophages, have pattern recognition receptors on the outer cell membrane called tolllike receptors (TLR) and internally in the cytoplasm called nucleotide-binding oligomerization domain proteins (NOD) (Akira, 2004).

Signaling PRR bind a vast number of microbial molecules, both from bacterial and viral agents (Nakayama et al. 1993). The most notably and researched of the signaling pattern-recognition receptors are TLR. The binding of microbial molecules to their corresponding TLR promotes both the synthesis and the release of intercellular regulatory molecules such as cytokines, which are crucial to the initiation of the innate and adaptive immune systems (Akira 2004). Aderem and Smith (2004) summarized the identification of 11 TLR. These TLR can work independently or with one another depending on the PAMP presented. TLR are found not only on cell surfaces, but also in the membranes of the endosomes used to degrade pathogens. Work by Pasare and Medzhitov (2004) showed that TLR 2 and TLR 6 work together during the recognition and binding of the LTA and peptidoglycan PAMP, with TLR 2 as the primary signal to initiate immune response and subsequent binding with TLR 6 a secondary reaction (Takeda, 2004). The binding of a pathogen to its corresponding TLR transmits a signal to the macrophage's nucleus via a nuclear factor, $\mathrm{NF}-\kappa \mathrm{B}$, which in turn causes the induction of gene expressions that code for specific cytokine synthesis (Takeda and Akira, 2005). Upon their induction, cytokines bind to their receptors on other cells, including those of the defense system, furthering the innate immunity cascade.

NOD are cytostolic proteins that allow intracellular recognition of peptidoglycan components. There are two NOD (Mueller and Podolsky, 2005). NOD 1 is essential in the recognition of peptidoglycan containing muramyl dipeptide NAG-Nam- $\gamma-\mathrm{D}-$ 
glutamyl-meso diaminopimelic acid; a common peptidoglycan monomer component in all gram-negative bacteria and a few gram-positive bacteria. On the other hand, NOD 2 recognizes a peptidoglycan component that is found in almost all bacteria, muramyl dipeptide NAG-NAM-L-alanyl-isoglutamine (Murillo et al., 2003).

In 2003, Girardin and colleagues observed that PAMP on peptidoglycan fragments that are in systemic circulation bind to TLR on macrophages and are broken down into muramyl dipeptides and endocytized. NOD 1 and/or NOD 2 located in the cytosol bind to the muramyl dipeptides leading to the activation of those genes that code for proinflammatory cytokines. The participation of NOD 1 or NOD 2 in the cytoplasm is carried out in a similar fashion as the cell surface TLR.

Cytokines are multifunctional, pleiotropic and redundant proteins that are activated during an innate immune response. Cytokines act as intracellular and intercellular signaling molecules that are synthesized and secreted by a variety of different cell types, as well as act on a range of target cells (van Deventer et al., 1990). A great example that shows the versatility of cytokine production and action is tumor necrosis factor- $\alpha$ (TNF- $\alpha)$, which is synthesized and secreted mainly by macrophages and mast cells. Red blood cells (RBC) are the only known cells that do not contain TNF- $\alpha$ receptors (Tizzard, 2004). Several cytokines can illicit the same cellular response, allowing an immune response to be activated via several different pathways, yielding in the same result. Additionally, the same cytokine has the ability to be a regulatory factor in a number of different cellular functions. While some cytokines initiate and amplify the response, others sustain or attenuate it (proinflammatory), and some cause it to resolve 
(anti-inflammatory). Depending on the origin of the cytokine synthesis stimulation, different patterns of cytokine release have been observed (Gruys et al., 2005).

Cytokines can be placed into one of two subcategories termed either T-helper 1 (Th-1) or T-helper 2 (Th-2) cytokines. Th-1 cytokines are primarily proinflammatory including TNF- $\alpha$, interleukin-1 (IL-1), interleukin-2 (IL-2), interleukine-8 (IL-8), and interferon- $\gamma($ IFN- $\gamma)$. Th-2 cells secrete interleukin-4 (IL-4), interleukin-5 (IL-5), interleukin 6 (IL-6), and interleukine-10 (IL-10), which down-regulate the inflammatory response (Mosmann and Coffman, 1989; Raghupathy, 1997). As stated by Agarwal et al. (2000) a successful pregnancy is the result of a fine balance between Th- 1 and Th-2 type cytokines that are involved throughout growth, development and maternal tolerance of the conceptus.

Cytokines such as TNF- $\alpha$, IL-1, IL-6, IL-12 and chemokines (glycoproteins with leukocyte activation and chemotactic activity) such as IL-8 are stimulated immediately after initiation of the innate immune system (Papanicolau et al., 1998). Upon activation of the cytokine cascade, not only is the innate immune system responsive, but the initiation of the acute phase response (APR) begins. The participating cytokines are considered to be proinflammatory, because they promote production and release of other cytokines and chemokines to amplify the immune response. Chemokines, like IL-8, are known to promote inflammation by acting chemotactically, enabling white blood cells (WBC) to leave the blood and by attracting those same WBC to the site of trauma or infection. Moreover, these same cytokines and chemokines not only play roles in a vast number of immune responses, but they are vital for homeostasis. As studied by Bagavandoss et al., (1988) and later by Murdoch et al., (1997), TNF- $\alpha$ is critical in 
ovulatory processes. Additionally, IL-1 has positive effects on the enhanced growth of fibroblasts, glial cells and vascular smooth muscle, all of which aid in daily cell growth and maintenance (Aggarwal and Natarajan, 1996).

TNF- $\alpha$ is the first cytokine to be synthesized and secreted by macrophages upon initiation by NF- $\mathrm{KB}$ in response to TLR or NOD binding. TNF- $\alpha$ is an essential mediator of inflammation working both independently and synergistically with IL-1 (Gupta, 2001). A local increase in TNF- $\alpha$ near the site of infection or trauma causes an inflammatory response, including heat, pain, and swelling in the surrounding tissue. This is accomplished by TNF- $\alpha$ causing an increase in production of angiotensin II (Ang II) and prostacyclin $\left(\mathrm{PGI}_{2}\right)$, both vasodilators, by local endothelial cells. Ang II and $\mathrm{PGI}_{2}$ cause capillaries to leak (Kuwano et al., 2004). This leakage allows neutrophils and other plasma proteins to enter tissue and augment the immune response. In addition, TNF- $\alpha$ acts on neutrophils directly by enhancing their ability to kill microbes and increasing adherence to vascular endothelium, as well as chemotactically attracting them to the site of tissue damage. Systemic TNF- $\alpha$ stimulates mast cells and macrophages to produce additional cytokines such as IL-1 and IL-6 (Blatteis, 2007).

Produced primarily by macrophages, IL- 1 has two isoforms IL- $1 \alpha$ and IL-1 $1 \beta$. IL$1 \beta$ is produced by 50 -fold more than its counterpart IL- $\alpha$, and while IL- $1 \beta$ is secreted into systemic circulation, IL-1 $\alpha$ remains attached to the macrophage from which it was produced. The mRNA for both isoforms of IL-1 increase significantly within 15 minutes after exposure to stimulus, continuing until it reaches its peak production at 3 to 4 hours post induction (Baggiolini, 2001). 
Once induced and circulating systemically, IL-1 can work independently or synergistically with other cytokines like TNF- $\alpha$. During times of infection, along with TNF- $\alpha$, IL-1 escapes from the bloodstream and causes a multitude of sickness behaviors. Synergistically they act on the brain to cause fever, lethargy, decreased appetite and general malaise (Uhlar and Whitehead, 1999). In addition, IL-1 and TNF- $\alpha$ are responsible for the activation of the production of another proinflammatory cytokine, IL6. As Steel (1994) described, IL-1 not only acts on muscle cells to mobilize amino acids causing pain and fatigue, but also on hepatocytes to enhance the production of acute phase proteins to assist with the host innate immunity, the later reaction accomplished indirectly with the stimulation of IL-6.

IL-6 is secreted from macrophages after the synergistic stimulation of TNF- $\alpha$ and IL-1, and bacterial endotoxins. IL-6 acts in a negative feedback fashion on TNF- $\alpha$ and IL-1 to control the immune response (Heinrich et al., 1990). Additionally, McWaters et al., (2000) showed that IL-6 regulates the transition from a neutrophil-dominated process early in inflammation to a macrophage-dominated process late, and for that is considered the major mediator of the acute phase reaction.

The mammalian acute phase response (APR) is the first line of systemic defense in response to infection, physical trauma, malignancy, myocardial infarction and surgery (Koj, 1985). APR is characterized by a wide range of neuroendocrine, hematopoietic, metabolic and hepatic changes (Ceciliani et al. 2002). Neuroendocrine changes observed are fever, poor appetite, somnolence, as well as increases in adrenocorticotropic hormone (ACTH), cortisol and catecholamine concentrations. In addition, an elevation in the circulating concentrations of hepatically synthesized acute phase reactants called acute 
phase proteins (APP) are observed at this time (Ceciliani et al., 2002). Optimally, the APR should begin several minutes after initial immune activation. Gruys et al. (2005) found that vaccinations and starvations can also cause initiation of APR. Regardless of the stimulation, these reactions aim to prevent ongoing tissue damage, isolate and destroy the invading microorganism, and activate the repair processes necessary to restore homeostasis in the host (Baumann and Gauldie, 1994). The APR begins immediately after a pathogenic or pathogenic-like stimuli has been initiated by proinflammatory mediators such as cytokines like IL-6, IL-1 $\beta$, IL-8, TNF- $\alpha$, INF- $\gamma$, transforming growth factor $\beta$ (TGF- $\beta$ ), glucocorticosteroids and anaphyltoxins (Kushner 1993; McCormack et al., 1996; Wigmore et al., 1997; Gabay and Kushner, 1999). The local inflammation in both cancer and infection is accompanied by APP upon activation by cytokines (Cavaillon and Duff, 1999).

Cytokines released from immune defense cells are transported through the blood and stimulate hepatocytes in the liver to synthesize and secrete APP. Upon stimulation of the APR the first APP are usually detected within one to two hour(s), and continue for one to two day(s). In addition to the APP production in the liver there is extrahepatic synthesis by macrophages, endothelial, and smooth muscle cells (Winter et al., 2006).

As shown by Wilson et al. (1984), APP are species specific. APP have been defined as any protein whose plasma concentrations increases (positive acute-phase proteins; fibrinogen, serum amyloid A, albumin, C-reactive protein) or decreases (negative acute-phase proteins; albumin, transferrin, insulin growth factor I) by at least 25 percent during an inflammatory disorder (Morley and Kushner, 1982). The major APP for humans are $\mathrm{C}$ reactive proteins (CRP) and serum amyloid A (SAA), for mice it is SAA, 
in cattle they are SAA, haptoglobin and lipopolysaccharide binding protein while in sheep both haptoglobin (Hp) and SAA are APP. APP are considered biomarkers for infection, functioning as soluble PRR. Additionally, each APP has individual actions against invading organisms. SAA is a strong opsinizing agent against invading pathogens, whereas Hp binds hemoglobin, and sequesters the iron within hemoglobin, preventing iron-utilizing bacteria from benefiting from hemolysis (Eaton et al., 1982; Uhlar and Whitehead, 1999). The production of APP enable the body to recognize possible pathogens early after infection, prior to full activation and implementation of a complete immune response. As with APR, the main stimulators of APP production are the inflammation-associated cytokines, which are produced as a result of, and participate in, the inflammatory processes (Tizzard 2004).

During the inflammatory response, TNF- $\alpha$ and IL-1 stimulate the anterior hypothalamus of the brain; the portion of the brain that regulates body temperature (Cid, 1992). This stimulation results in an increased production of prostaglandins, which lead to sympathetic nerve stimulation and vasoconstriction of skin vessels, which ultimately leads to an increase in body temperature, or a phenomenon that is most commonly referred to as fever (van Deventer et al., 1990).

Within certain parameters, fever is not detrimental, but actually beneficial. Fever causes the host environment to move above the optimal temperature for a number of microorganisms, thus slowing down their growth. While the growth rate of the invading pathogen has decreased, the host body's defense system has a chance to gain ground in the elimination and removal of the pathogen. Fever continues the ongoing secretion of proinflammatory cytokines by its direct action in the production of heat shock proteins. 
An increase in body temperature causes an increase in enzymatic activity that in turn results in an increase in the host metabolism. By speeding up the metabolic rate of the host we can see a rise in defense cell and antibody production, allowing for a greater immune response. However, a fever that becomes too high can cause extensive and possibly irreversible damage to the host. At an excessively high body temperature, or chronic fever, enzymes along with other proteins can become denatured, an

overabundance of cytokines can be stimulated resulting in tissue damage that may not be able to be repaired, multiple organ failure occurs as a result of tissue damage and septic shock or systemic inflammation response syndrome (SIRS) occurs (Kengatharanetal, 1998; Pechlaner, 2002) (Kluger et al., 1995). Over 210,000 people a year in the United States alone die from septic shock with $45 \%$ of cases of septicemia due to gram-positive bacterial infections (Morris, 2001).

\section{$\underline{\text { Adaptive Acquired Immunity }}$}

Unlike the quick acting innate immune system, the adaptive or acquired immune system is just as its name implies, acquired over time. Adaptive immunity is an antigenspecific mechanism that takes several days to weeks to become active. Once the innate immune response is activated via pathogen detection, and the acute phase response has been initiated, the host body is then able to accurately begin to determine the specifics of the given antigen and correspondingly trigger an adaptive immune response.

Within the adaptive immune response there are two subcategories: humoral and cell-mediated immunity. Humoral immunity produces antibodies in response to a specific antigen. Immunogens, antigens capable of provoking an immune response, have specific areas on their surface, called epitopes, which will react with 
receptors on the host lymphocytes and antibodies (Pasare et al., 2004). The host body recognizes an antigen as foreign only when immunogen epitopes bind to their receptors on T-lymphocytes (T-cells) or B-lymphocytes (B-cells) via epitope-specific receptor molecules. Unlike the receptors on T-cells that only recognize epitopes, B-cell receptors are able to directly bind epitopes on antigens allowing for the mass production of antibodies for that given antigen. It is the B-cells that mediate the production of antibodies via activation of the humoral pathway (Goldsby et al., 2003).

While the humoral pathway is mediated by B-cells, the cell-mediated immunity is carried out by T-cells. T-cells mediate the activation of macrophages and natural killer cells, the production of cytotoxic T-lymphocytes and cytokines all in response to an immunogen. Furthermore, T-cells have the ability to recognize immunogen epitopes and discriminate self from non-self via major histocompatible complex I molecules (MHC I) (Huber et al., 1976).

MHC I molecules are produced by all nucleated cells in the host. MHC I molecules join themselves with a variety of peptide derived cytocylic proteins from degraded pathogens via proteosomes. Once attached, the MHC I molecules along with the peptide epitope is able to be recognized by a complementary-shaped receptor on the surface of a naïve T-8 lymphocyte. This naïve T-8 lymphocyte then has the ability to clone the presented peptide epitope. The T-8 lymphocyte is able to produce mature Tcells that will have receptors for the specific antigen and be able to bind the pathogen epitope directly. Thus, the initiation of the adaptive immune system via cell-mediated immunity has begun (Marrack and Kappler, 1993). An added feature of MHC I molecules is their function, when unbound, as a marker for the immune system, 
collectively, to differentiate between cells that are self from those that are foreign. All cells that are not marked with unbound MHC I molecules are identified by natural killer cells (NKC) as pathogenic and phagocytized.

In addition to the MHC I molecules that aid in cell-mediated immunity in the recognition of immunogens, both the humoral and cell-mediated immune systems also utilize MHC II molecules. Unlike MHC I molecules, MHC II molecules are only found in macrophages, dendritic and B-cells, and bind peptides derived from extracellular pathogenic proteins. Once bound, MHC II molecules interact exclusively with $\mathrm{CD}^{+}{ }^{+} \mathrm{T}$ cells (helper T cells). The helper T cells then help to trigger an appropriate immune response which may include localized inflammation and swelling due to recruitment of phagocytes or may lead to a full-force antibody immune response due to activation of B cells (Amilla et al., 1998).

\section{$\underline{\text { Summary }}$}

Bacterial infections, like mastitis, continue to be costly, unresolved problems for the dairy industry. Bacterial cell wall components peptidoglycan and LPS can illicit innate immune system responses that can contribute to a number of homeostatic disturbances. Fever, lethargy, loss of appetite, and general malaise seem to be consistent characteristics of bacterial infections, and can act as markers that show an acute phase response has been initiated via cytokines, chemokines and acute phase proteins. Additionally, bacterial pathogens that invade pregnant animals may also be potentially dangerous to the embryo as well. The aim of this study was to further examine possible embryonic loss due to mastitis and in doing so gain a better understanding of the mechanisms behind such loss. 


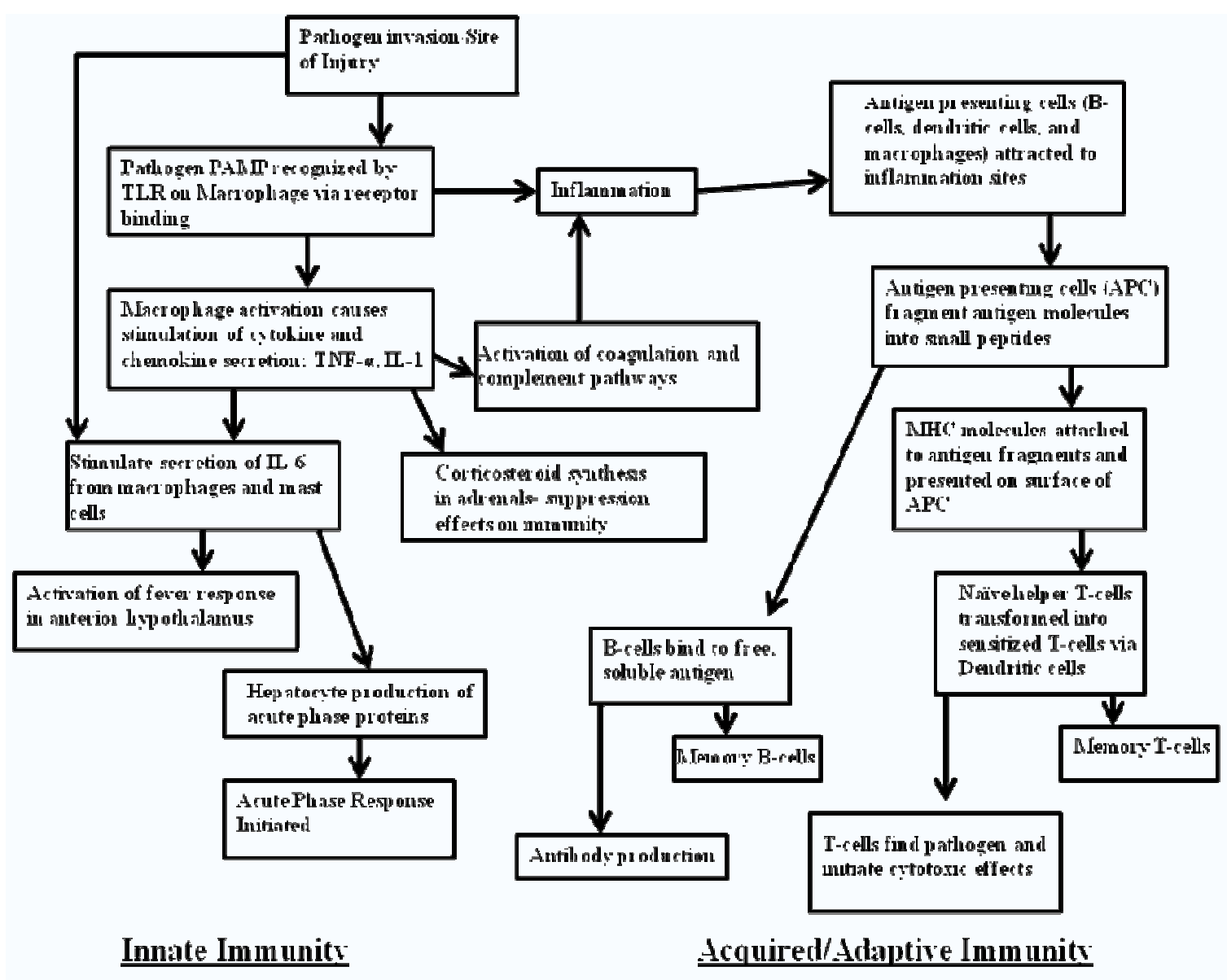

Figure 1. Innate and Acquired/Adaptive Immune Response Summary 


\section{Introduction}

Barker et al. (1998) investigated the influence bacterial infections, such as mastitis, has on reproductive performance. Dairy cows having contracted mastitis post partum during early lactation, but before the first artificial insemination (AI), required on average 20 more days before showing visible signs of estrus. Additionally, if cows contracted mastitis between the time of the first AI and confirmation of pregnancy, they required 1.5 more inseminations before pregnancy was confirmed, thus increasing the length of the breeding period by approximately 55 days. Moreover, Barker et al. concluded that bacterial infections have a negative affect on reproductive performance.

To determine the possible bacterial induced mechanism affecting reproductive performance, Stewart et al. (2003) examined the immune response and its potential physiological influences in the early pregnant ewe. Using three concentrations, 15,30, and $60 \mu \mathrm{g} / \mathrm{kg}$ body weight, of a bacterial cell wall component, peptidoglycanpolysaccharide (PG-PS), injected intravenously, an immune response was illicited. Through plasma samples collected via jugular blood, Stewart et al. were able to show that all PG-PS concentrations caused an increase in body temperature, as well as increases in cortisol and PGFM, a Prostaglandin- $\mathrm{F}_{2 \alpha}$ metabolite. Furthermore, plasma concentrations of progesterone decreased in all treated ewes compared to that of controls. Pregnancy loss was analyzed and found to be $0 \%$ in controls and those ewes treated with $15 \mu \mathrm{g} / \mathrm{kg}$ body weight PG-PS compared to a combined $40 \%$ in those dosed with 30 and $60 \mu \mathrm{g} / \mathrm{kg}$ body weight PG-PS.

Based on previous findings from Barker et al. (1998) and Stewart et al. (2003) showing that an immune reponse due to a bacterial infection occurs and that such an 
occurance can compromise reproductive performance, Holásková et al. (2004) examined the time at which an immune response to a bacterial infection occurs; during the innate or the adaptive immune response. If a response was during the adaptive period, it was hypothesized that it may be possible to vaccinate against a bacterial invasion, thus preventing pregnancy loss. Challenging ewes with $60 \mu \mathrm{g} / \mathrm{kg}$ body weight PG-PS either after immunization with $30 \mu \mathrm{g} / \mathrm{kg}$ body weight PG-PS or heat killed bacterial cells, Holásková et al. found that pregnancy loss occurred more in those animals who were vaccinated. Evidence from this experiment proved that an insult from a bacterial invasion resulting in embryonic loss occurs early during the innate immune response.

To further the understanding of when and how an innate immune response can lead to pregnancy loss during a bacterial infection, Rogers (2006) looked at the inflammatory mediator TNF- $\alpha$ and acute phase protein SAA. By monitoring the production of TNF- $\alpha$ and SAA, Rogers was able to determine when an immune response commenced and if the response was a systemic or local response, regardless of site of PG-PS injection. A catheter was placed in the jugular vein, as well as the saphenous vein of the right hind leg to allow for sampling of the caudal vena cava. Since the circulating blood travels from the reproductive tract into the caudal vena cava, an estimate of inflammatory mediator and hormone concentrations could be analyzed as that of local exposure to the tract. After an intravenous injection of $30 \mu \mathrm{g} / \mathrm{kg}$ body weight PG-PS given in the jugular vein contralateral to the catheter, data revealed that ewes challenged with PG-PS experienced an increase in both TNF- $\alpha$ and SAA concentrations when compared to controls. Moreover, there was also a significant increase in concentration of TNF- $\alpha$ in blood from the caudal vena cava compared to that of the jugular. Therefore, 
Rogers concluded that there was an increased local exposure to TNF- $\alpha$ of the reproductive tract, and with the increase in SAA concluded that an immune response due to a bacterial infection acts through the acute phase response.

\section{Objectives}

At 5 and 6 days post coitus (dpc), the embryo is a free-floating entity vulnerable to maternal immune responses. As the reproductive tract becomes a site for an inflammatory reaction, concentrations of pro-inflammatory cytokines, chemokines, localized invasion of immune cells, as well as systemic increases of acute phase proteins (APP) will increase. The null hypotheses for this experiment is injection of 5 and $6 \mathrm{dpc}$ pregnant ewes with peptidoglycan-polysaccharide (PG-PS) does not illicit a difference in concentration of proinflammatory cytokines, tumor necrosis factor- $\alpha$ (TNF- $\alpha$ ), and acute phase proteins (APP), serum amyloid A (SAA) and haptoglobin (Hp), between plasma collected from the jugular vein (representative of systemic circulation) or that from the caudal vena cava via saphenous vein (representative of local reproductive tract circulation). Moreover, increased TNF- $\alpha$, SAA, Hp concentrations in blood plasma of 5 and 6 dpc pregnant ewes was hypothesized to not either directly or indirectly cause early embryo loss. The main objectives of this project were to characterize the effects of an acute phase response (APR) of the innate immune system, via cytokine production, acute phase proteins, behavioral changes, and fever, in early pregnant ewes, after intoxication with PG-PS, to investigate for an effect of APR on early embryonic loss. 


\section{Materials and Methods}

Thirty mature Suffolk ewes, 80 kg BW, (WVU IACUC \#9801-06) were fed corn silage and haylage twice a day and had access to fresh water ad libitum. Ewes were housed with a vasectomized ram fitted with a marking harness to aid in detection of

estrus. Fifteen ewes that had exhibited two consecutive, estrous cycles of 16 to 18.5 days in length were given two, $1 \mathrm{cc}(5 \mathrm{mg}$ per $\mathrm{mL})$ intramuscular injections of $\mathrm{PGF}_{2} \alpha$ (Lutalyse $^{\circledR}$, Pharmacia and UpJohn, New York, NY) 3 hours apart (Inskeep et al., 1983) to synchronize estrus. Every 12 hours ewes were observed for signs of mounting. Marked ewes were removed from the flock and mated by two fertile rams. A replicate of 15 ewes was synchronized and bred seven days later (12/10-12/11/06). In each group, 10 ewes successfully mated.

Day of the first breeding was denoted as $0 \mathrm{dpc}$. On $4 \mathrm{dpc}$, ewes were anesthetized with Diazepam®, 0.3 mg/kg BW iv, (Hoffmann-La Rouche Inc., Nutley, NJ) and Ketamine ${ }^{\circledR}, 0.7$ mg/kg BW, (Phoenix Pharmaceuticals Inc., Mountain View, CA). Once mildly sedated ewes were maintained anesthetized using isoflurene gas via an intratracheal tube. The area around the right hock leg was shaved and scrubbed with Betadine ${ }^{\circledR}$ (The Perdue-Frederick Company, Stamford, CT), and treated with $\sim 3 \mathrm{~mL}$ Lidocaine® (Butler Company, Columbus, $\mathrm{OH}$ ). The skin over the hock was tented using a pair of forceps and slit approximately $1 \mathrm{~cm}$. The saphenous vein was isolated by blunt dissection, incised using a pair of iridectomy scissors. A polyvinyl catheter (id 0.040" and od 0.070") (Cole-Parmer, Vernon Hill, IL) was inserted into the saphenous vein $55 \mathrm{~cm}$ to sample blood draining the reproductive tract (Benoit and Dailey, 1991) and anchored with dissolvable suture. Catheters were flushed with $2 \mathrm{cc}$ of heparinized saline and 
capped with an 18 gauge, 1 inch needle with a filed off tip fitted into the tube. The catheter site was closed with 1 to 2 sutures and dressed with Furazolidone ${ }^{\circledR}$ (Veterinary Products Laboratories, Phoenix, AZ), covered with 4" by 4" sterile gauze pads and wrapped with Vetrap® $(3 \mathrm{M} ®$, St. Paul, MN). The right jugular fossa area was scrubbed with Betadine®, and the right jugular vein was catheterized with an I-CATH Intravenous Placement Unit with Stylet® (CharterMed, Inc., Lakewood, NJ). The area around the catheter was treated topically with Furazolidone®, covered with 4" by 4" sterile gauze pads and wrapped with Vetrap®. Ewes recovered immediately following surgery and were housed post-operatively two ewes per pen at the Food Animal Research Facility with a room temperature maintained at $\sim 18{ }^{\circ} \mathrm{C}$.

On 5 dpc ewes were assigned to one of two treatment groups per pen: controls received $10.67 \mathrm{cc}$ of $0.9 \%$ saline and treated ewes received $10.67 \mathrm{cc}$ of $60 \mu \mathrm{g} / \mathrm{kg}$ PG-PS (BD Lee Laboratories, Grayson, GA) in the jugular vein contralateral to the catheter. Blood samples $(6-8 \mathrm{ml})$ were collected into EDTA treated tubes every fifteen minutes post challenge for 120 minutes, every hour to 12 hours, and every 12 hours until 48 hours. Samples were centrifuged, and plasma was collected and stored at $-20^{\circ} \mathrm{C}$ until assayed. Changes in body temperature, behavior and/or physical appearance were recorded. At 48 hours, saphenous and jugular vein catheters were removed and the sites were dressed topically with Furazolidone®, covered with 4" by 4" sterile gauze pads and wrapped with Vetrap®. Ewes were returned to the sheep facility and placed with a vasectomized ram fitted with a marking harness. At days 14 and 21 of gestation, jugular blood samples were collected in EDTA treated tubes, in addition to transrectal ultrasonography for detection of pregnancy on day 21 (Schrick and Inskeep, 1983). 


\section{$\underline{\text { Assays }}$}

Concentration of $\mathrm{P}_{4}$ in jugular plasma (100 $\mu$ l of sample/tube) was determined by radioimmunoassay (Sheffel et al., 1982). Assay sensitivity was $0.29 \mathrm{ng} / \mathrm{ml}$ and intraassay and inter-assay coefficient of variation averaged $7 \%$ and $14.8 \%$ respectively among three assays.

TNF- $\alpha$ was assayed in both jugular and caudal vena cava plasma samples $(100 \mu 1$ sample/tube) using a non-equilibrium RIA (Kenison et al., 1990) at the USDA Growth Biology Laboratory (Beltsville, MD). Samples were analyzed in duplicate with an intraassay coefficient of variance less than $7 \%$.

SAA concentrations were determined using a multispecies SAA solid phase ELISA kit (Invitrogen Corporation, Carlsbad, CA). The protocol supplied with each kit was followed to process duplicate plasma samples $(4 \mu \mathrm{L}$ sample $+396 \mu \mathrm{L}$ S/CD buffer, then $5 \mu \mathrm{L}$ sample $+145 \mu \mathrm{L} \mathrm{S/CD}$ buffer) diluted 1:3000. SAA concentrations were reported in $\mathrm{ng} / \mathrm{mL}$ with an assay sensitivity of $0.3 \mu \mathrm{g} / \mathrm{mL}$ and an intra-assay coefficient of variance of $9.8 \%$ among ten assays.

Hp concentrations were determined using multispecies Hp colormetric kits (Phase TM Range, Tri-Delta Diagnostics Inc., Morris Planes, NJ). Plasma samples were diluted 1:3 (25 $\mu \mathrm{L}$ sample $+50 \mu \mathrm{L}$ diluent buffer) and tested in duplicates. Hp concentrations were reported in $\mathrm{mg} / \mathrm{mL}$. Hp ELISA sensitivity was $0.05 \mathrm{mg} / \mathrm{ml}$, with an intra-assay coefficient of variance of $6.9 \%$ for two assays. 


\section{$\underline{\text { Statistical Analysis }}$}

Primary Null Hypotheses:

1. The concentration of TNF- $\alpha, \mathrm{SAA}$ and Hp in blood plasma collected from either the jugular vein or the caudal vena cava via saphenous vein for a given time period does not differ between 5 and 6 dpc pregnant ewes intoxicated with an injection of PG-PS or those given a sham injection of $.9 \%$ saline.

2. Intoxication of 5 and 6 dpc pregnant ewes with PG-PS does not illicit a difference in TNF- $\alpha$ concentrations between plasma collected from the jugular vein or that from the caudal vena cava via saphenous vein.

3. Increased TNF- $\alpha$, SAA, Hp concentrations in blood plasma of day $5 / 6$ pregnant ewes does not contribute to early embryo loss.

Data for concentrations of $\mathrm{P}_{4}, \mathrm{TNF}-\alpha, \mathrm{SAA}$, and $\mathrm{Hp}$ were analyzed by repeated measures ANOVA GLM procedure of SAS (SAS Inst., Cary, NC). P-values less than 0.05 were considered significant. Immune response was determined by fever, increases in SAA and Hp concentrations, as well as veterinary diagnostic hemagrams and large animal blood chemistry panels (Cornell University, Animal Health Diagnostic Center, Ithaca, NY). 


\section{$\underline{\text { Results }}$}

Body temperature was higher $\left(40.3^{\circ} \mathrm{C}\right)$ for treated ewes compared to the average controls $\left(39.1^{\circ} \mathrm{C}\right)$ at the peak of the fever response. Body tempearture increased in treated ewes beginning at $\sim 3$ hours post treatment, peaked at 12 hours post, and had resumed to normal parameters at 24 hours post. In addition, treated ewes showed a decrease in appetite, lethargy, and general malaise. A muco-purulant vaginal discharged was observed in all treated ewes at $\sim 3$ hours post intoxication, persistedfor 24 hours, and cleared to a watery discharge at 48 hours. Thus, an innate immune response was initiated and localized inflammation occurred within the reproductive tract..

At $14 \mathrm{dpc}$ all ewes in both treatment and control groups exhibited $\mathrm{P}_{4}$ concentrations, mean $1.60 \mathrm{ng} / \mathrm{mL}$ and $2.14 \mathrm{ng} / \mathrm{ml}$ respectively, indicative of pregnant ewes (Bassett et al., 1969) (Table 1). At $21 \mathrm{dpc}, \mathrm{P}_{4}$ concentrations decreased significantly $<0.74 \mathrm{ng} / \mathrm{ml}(\mathrm{p}<0.01)$ in all treated ewes, but had increased to $2.40 \mathrm{ng} / \mathrm{ml}$ in control ewes. Viable embryo(s) and CL were observed in all control ewes and 0\% embryo(s) or CL in the treated ewes. Ultrasonography at $21 \mathrm{dpc}$ corresponded with $\mathrm{P}_{4}$ concentrations whereas viable embryos and CL(s) were observed in $100 \%$ of control group ewes and $0 \%$ embryos or CL(s) for all ewes in the treatment group.

Treatment of ewes with $60 \mu \mathrm{g} / \mathrm{kg} \mathrm{BW}$ PG-PS $(\mathrm{n}=8)$ increased $(\mathrm{p}<0.001)$ production of TNF- $\alpha$ measured in caudal vena cava via saphenous vein compared to jugular vein (Figure 2). Additionally, concentration of TNF- $\alpha$ was increased $(p=0.02)$ in control ewes $(n=4)$ compared to treated ewes $(n=4)($ Figure 3).

Plasma SAA concentrations increased in all ewes compared to baseline values at 0 hours (Figure 4). SAA concentrations for the treated ewes differed $(\mathrm{p}<0.0001)$ from 
those in controls with a biphasic pattern in treated ewes (peaks at 2 hours and at 6 hours) exhibiting a 5 fold increase compared to baseline values.

Hp concentrations began to increase at 1 hour and continued to increase until 48 hours where a plateau was observed in all treated ewes (Figure 5). There was a significant difference in haptoglobin concentrations between treated and control ewes $(\mathrm{p}<0.0001)$, with a mean concentration of $1.10 \pm 0.20 \mathrm{mg} / \mathrm{mL}$ for treated and $0.45 \pm 0.10$ $\mathrm{mg} / \mathrm{mL}$ for controls. When compared to baseline concentrations, the treatment group had a 10 fold increase in Hp concentration, whereas there was no change among control ewes. 


\begin{tabular}{|c|c|c|c|c|c|c|c|c|}
\hline & & & & & & $14 \mathrm{dpc}$ & $21 \mathrm{dpc}$ & \\
\hline $\begin{array}{c}\text { EWE } \\
\#\end{array}$ & Group & $\begin{array}{l}\text { TEMP } \\
0 \mathrm{hr}\end{array}$ & $\begin{array}{l}\text { TEMP } \\
12 \mathrm{hrs}\end{array}$ & $\begin{array}{l}\text { TEMP } \\
48 \mathrm{hrs}\end{array}$ & $\begin{array}{c}\text { vaginal } \\
\text { discharge }\end{array}$ & $\begin{array}{c}\text { progesterone } \\
(\mathrm{ng} / \mathrm{ml})\end{array}$ & $\begin{array}{c}\text { progesterone } \\
(\mathrm{ng} / \mathrm{ml})\end{array}$ & $\begin{array}{l}\text { Ultrasound } \\
\text { Results }\end{array}$ \\
\hline 5222 & C & 102.5 & 102.9 & 102.8 & no & 2.12 & 2.16 & Pregnant \\
\hline 5168 & C & 101.2 & 101.0 & 101.0 & no & 1.32 & 1.40 & Pregnant \\
\hline 5166 & C & 102.2 & 102.6 & 102.8 & no & 3.24 & 3.30 & Pregnant \\
\hline 5202 & C & 102.8 & 102.5 & 102.0 & no & 2.08 & 2.10 & Pregnant \\
\hline 5148 & C & 102.1 & 102.4 & 101.9 & no & 2.70 & 2.44 & Pregnant \\
\hline 5164 & C & 103.1 & 103.0 & 103.1 & no & 2.64 & 2.80 & Pregnant \\
\hline 5146 & $C$ & 103.0 & 103.0 & 102.6 & no & 2.40 & 2.14 & Pregnant \\
\hline 69 & $C$ & 101.8 & 102.2 & 102.2 & no & 2.61 & 2.30 & Pregnant \\
\hline 549 & C & 102.0 & 101.9 & 102.0 & no & 2.12 & 2.32 & Pregnant \\
\hline & & 102.3 & 102.4 & 102.3 & & 2.14 & 2.40 & \\
\hline 1 & & & & & & 000 & 086 & Onen \\
\hline 3 & $\begin{array}{l}\mid \text { TRI } \\
\text { TRT }\end{array}$ & $\begin{array}{l}102.1 \\
101.0\end{array}$ & $\begin{array}{l}103.9 \\
104.8\end{array}$ & $\begin{array}{l}102.4 \\
101.8\end{array}$ & $\begin{array}{l}\text { yes } \\
\text { yes }\end{array}$ & $\frac{0.00}{2.42}$ & $\begin{array}{l}0.86 \\
0.74\end{array}$ & Open \\
\hline 99 & TRT & 102.2 & 103.3 & 102.4 & yes & 2.08 & 0.66 & Open \\
\hline 4287 & TRT & 103.0 & 104.4 & 102.8 & yes & 1.08 & 0.66 & Open \\
\hline 5225 & TRT & 102.8 & 105.1 & 103.0 & yes & 2.78 & 0.00 & Open \\
\hline 5151 & TRT & 101.8 & 105.6 & 102.2 & yes & 2.42 & 1.04 & Open \\
\hline 3149 & TRT & 102.4 & 105.0 & 102.4 & yes & 1.12 & 0.00 & Open \\
\hline 400 & TRT & 102.6 & 104.6 & 102.8 & yes & 0.00 & 0.96 & Open \\
\hline 4304 & TRT & 102.0 & 105.6 & 102.4 & yes & 0.00 & 1.10 & Open \\
\hline 346 & TRT & 101.0 & 102.9 & 101.6 & yes & 1.57 & 0.32 & Open \\
\hline & & 102.1 & 104.5 & 102.4 & & 1.60 & 0.74 & \\
\hline
\end{tabular}

Table 1, Plasma Progesterone Concentrations at 14 and $21 \mathrm{dpc}$ in Jugular Blood, Mean Body Temperatures, Vaginal Discharge and Ultrasonography Results in Suffolk Ewes. $\mathrm{C}=$ control, $\mathrm{TRT}=$ treated with $60 \mu \mathrm{g} / \mathrm{kg} \mathrm{BW} \mathrm{PG-PS}$ 


\section{TNF- $\alpha$ Concentrations Between Sampling Sites in Treated Ewes}

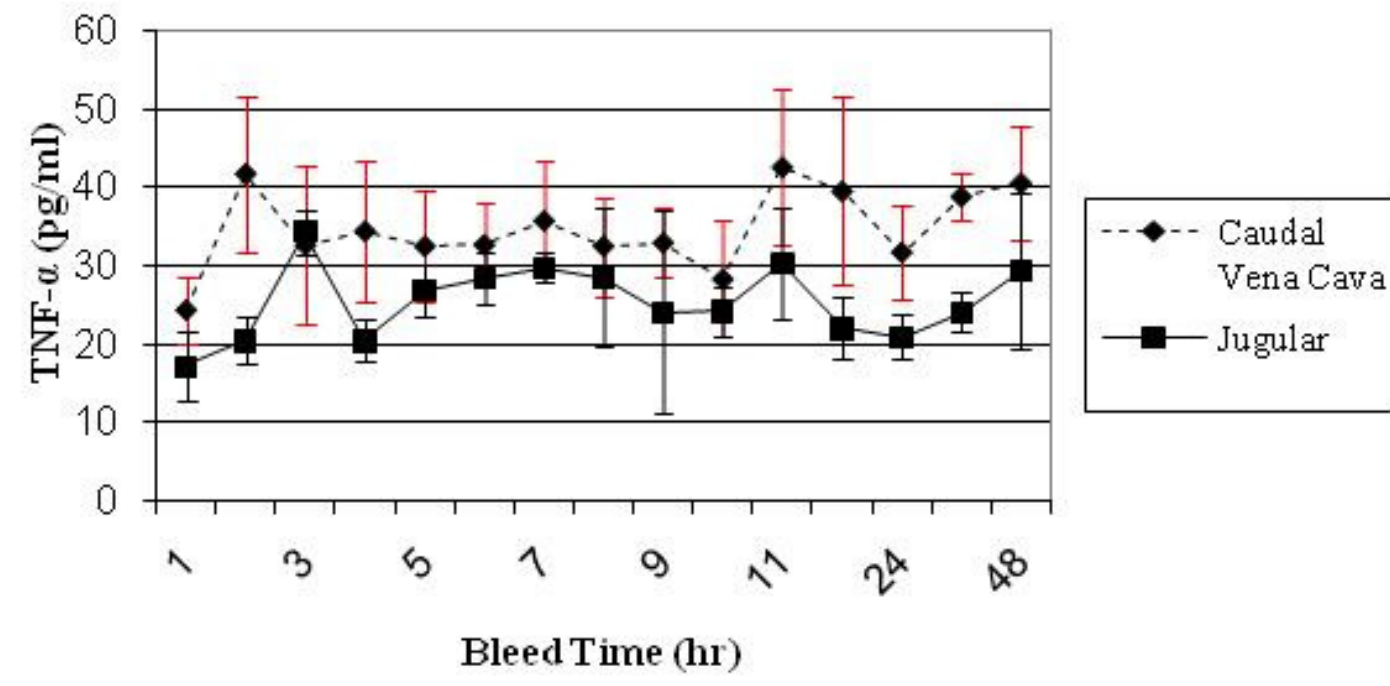

Figure 2, TNF- $\alpha$ Concentrations Between Sampling Sites; Caudal Vena Cava via Saphenous Vein and Jugular Blood in Suffolk Ewes. $n=8, p<0.001$ 


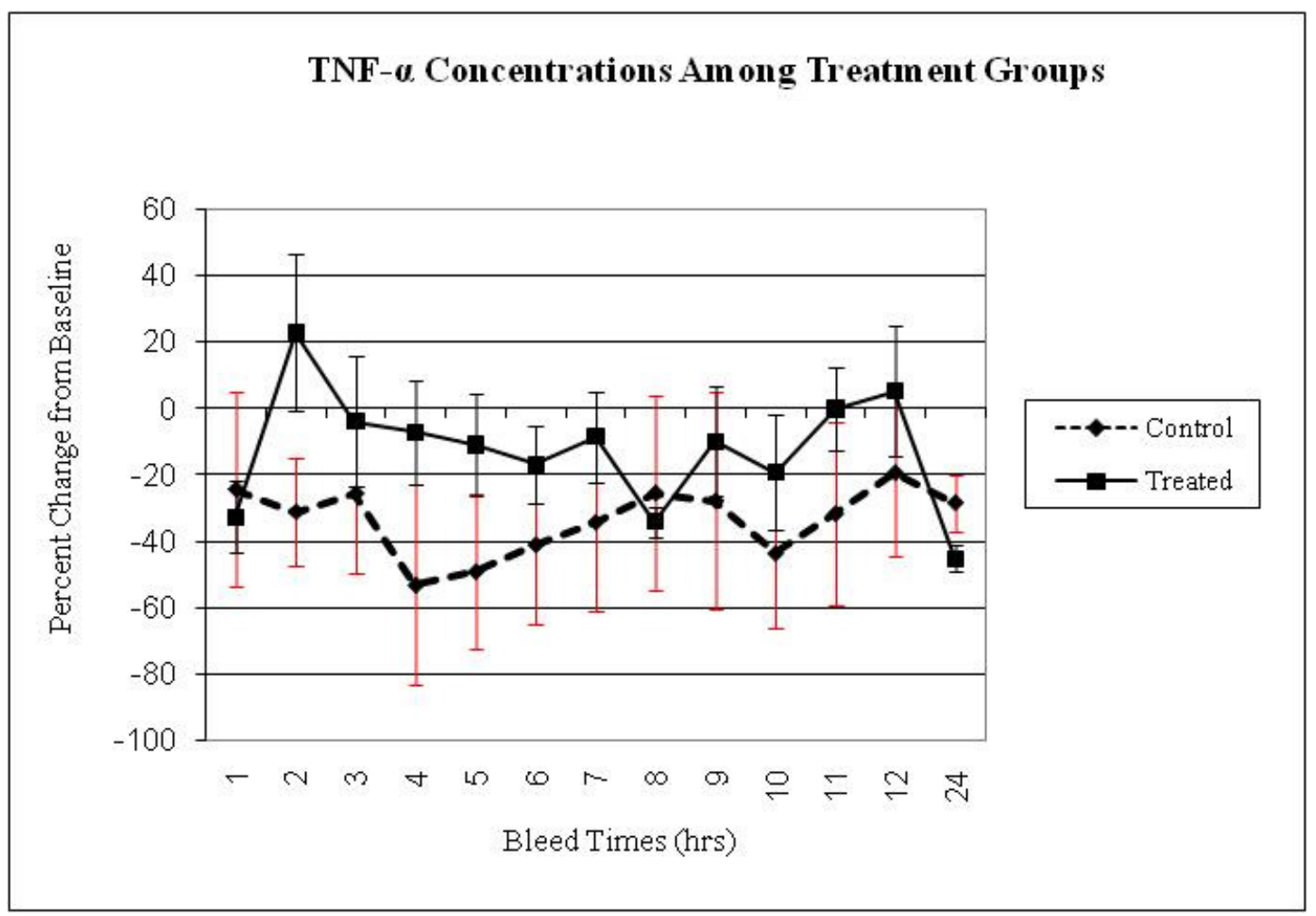

Figure 3, Plasma TNF- $\alpha$ Concentrations in Caudal Vena Caval Blood in PG-PS Treated Suffolk Ewes. $n=8, p=0.02$ 


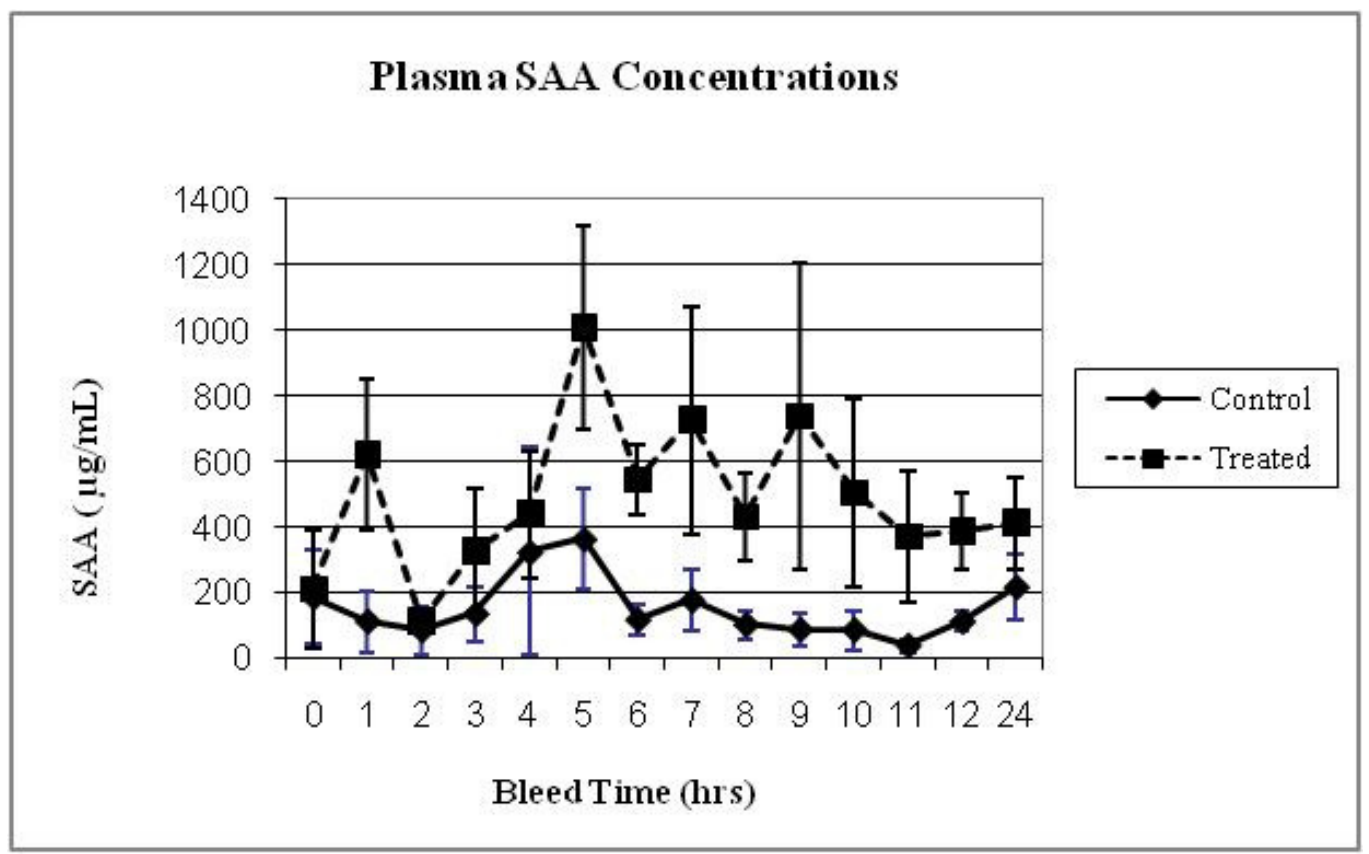

Figure 4, Plasma Concentrations of Serum Amyloid A in Jugular Blood in Suffolk Ewes. $\mathrm{n}=19, \mathrm{p}<0.0001$ 


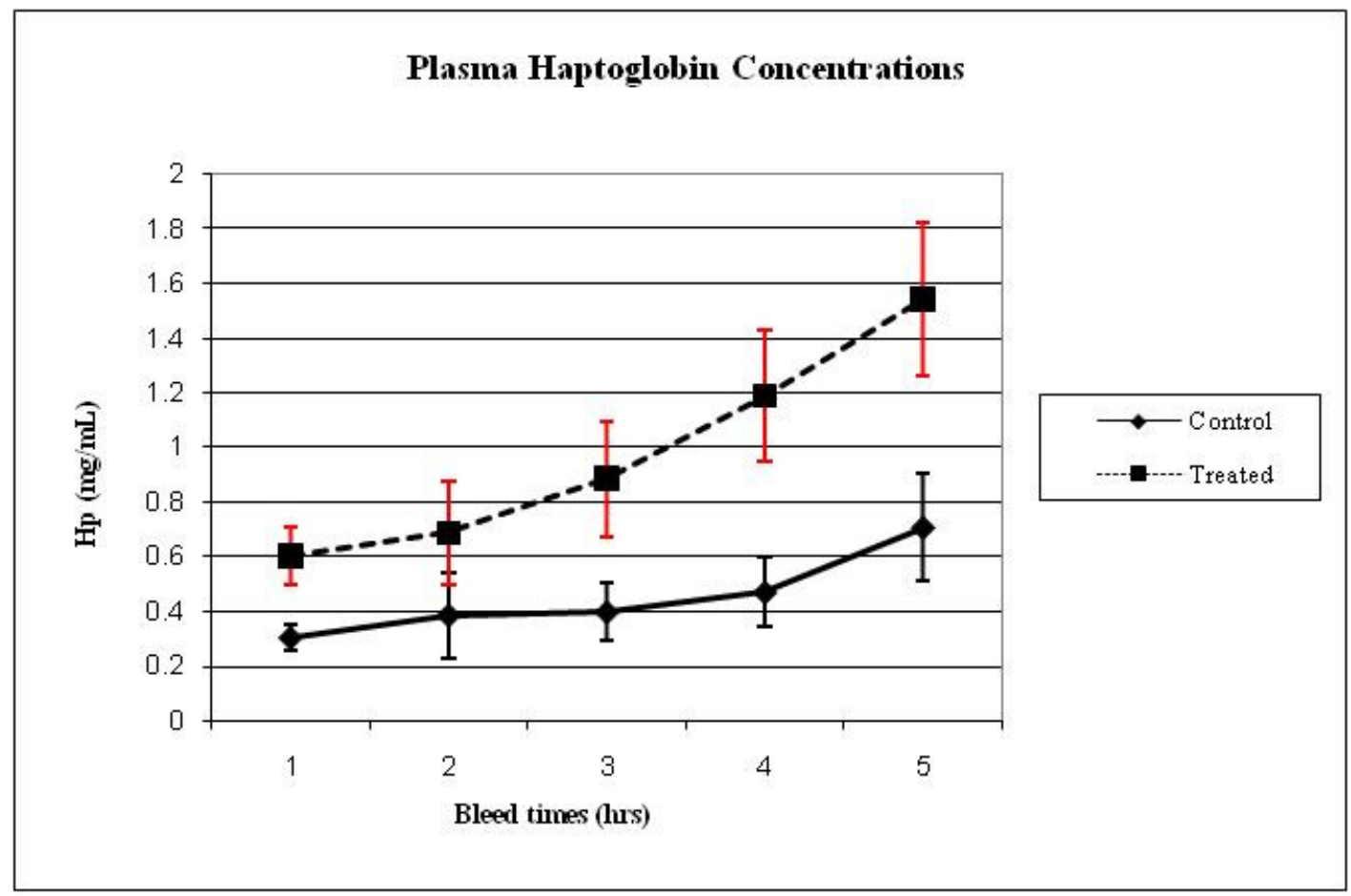

Figure 5, Plasma Concentrations of Haptoglobin in Jugular Blood in Suffolk Ewes. $\mathrm{n}=19, \mathrm{p}<0.0001$ 


\section{$\underline{\text { Discussion }}$}

Stewart et al. (2003) observed that in addition to increased body temperature and concentration of plasma cortisol , ewes intoxicated with a medium, $30 \mu \mathrm{g} / \mathrm{kg} \mathrm{BW}$, or high dose, $60 \mu \mathrm{g} / \mathrm{kg} \mathrm{BW}$ PG-PS had an increased pregnancy loss $40 \%$ verses $0 \%$ in control. In the current experiment a dose of $60 \mu \mathrm{g} / \mathrm{kg}$ BW PG-PS illicited an increase in body temperature by $2.5^{\circ} \mathrm{C}$ higher than in controls, as well as resulted in $100 \%$ embryonic loss for treated ewes compared to $0 \%$ loss in controls. Rogers (2006) found that a dose of $30 \mu \mathrm{g} / \mathrm{kg} \mathrm{BW}$, PG-PS was sufficient to elicit an immune response characterized by an increase in vena cava TNF- $\alpha$ concentrations. At present, a PG-PS dose of $60 \mu \mathrm{g} / \mathrm{kg} \mathrm{BW}$ supported work by Rogers (2006) resulting in a difference in TNF- $\alpha$ concentrations among sampling sites and in treated compared to control groups. However, in contrast, TNF- $\alpha$ concentrations were higer in control ewes compared to treated ewes with a dose of $60 \mu \mathrm{g} / \mathrm{kg}$ BW PG-PS. Possibly, the anesthetic, ketamine, diazapam, and isoflurene gas, used for the saphenous vein catheter placement surgery affected the response. In the mouse (Takenaka et al., 1994), the use of Diazapam, Isoflurene or Halothane gas caused a suppression in endotoxin-induced TNF- $\alpha$ concentrations for up to 36 hours after administration. Additional work in mice (Shaked et al., 2004) and human beings (Beilin et al., 2007) showed similar results.

Acute phase proteins, SAA and Hp, are stimulated by IL-6 at the initiation of the acute phase response, within hours of injury and usually subside within 24 to 48 hours. Used as biomarkers for infection, acute phase proteins themselves act as important components of the innate immune system including clotting molecules, protease inhibitors, and metal-binding proteins (Tizzard, 2004). Both SAA and Hp concentrations 
were observed to be significantly different among treated and controls for this experiment, with treated ewes experiencing a 5 fold and 3 fold increase from baseline, respectively. Therefore, with an increase in acute phase proteins it is logical to conclude that a dose of $60 \mu \mathrm{g} / \mathrm{kg} \mathrm{BW}$, PG-PS illicited an acute phase response of the innate immune system.

In the current research, all treated ewes had a significant increase in body temperature, fever, behavioral changes characterisitc of a sick animal, and vaginal discharge. Fever along with vaginal discharge allows the conclusion that not only did challenged animals experience a systemic inflammatory response, but also a localized response in the reproductive tract. In addition, treated ewes experienced $100 \%$ embryonic loss when compared to controls, with losses occuring between time of PG-PS intoxication at 5-6 dpc until 14 to $21 \mathrm{dpc}$ when transrectal ultrasound and plasma $\mathrm{P}_{4}$ concentrations were sampled. Although pregnancy loss corresponding with activation of an acute phase response via bacterial infection has yet to be formally characterized, some possible mechanism behind such embryonic loss could be:

1. Disruptions in the hypothalamic-pituitary-adrenal axis via disruption in $\mathrm{CL}$ lifespan via increases in $\mathrm{PGF}_{2 \alpha}$ or increased cortisol concentrations could be a possibility. A reaction to stress with in an organism is an increase in production of cortisol by the adrenal cortex. Once in circulation cortisol can act directly or indirectly in the stimulation of $\mathrm{PGF}_{2 \alpha}$ in uterine endometrium, and in the suppression of GnRH production resulting in a decrease in $\mathrm{LH}$ and thus a decrease in $\mathrm{P}_{4}$ which would ultimately result in the death of the CL. 
With the CL being the main producer of $\mathrm{P}_{4}$, the pregnancy maintainance hormone, at this time in gestation, embryo loss would be eminant.

2. As shown by Hansen et al. (2007), the early embryo, day $2-7 \mathrm{dpc}$, is vulnerable to endogenous toxins within the uterine environment. Using TNF- $\alpha$ Hansen and colleagues showed that embryo during this time of gestation are susseptible to invasion of such a molecule, across the zona pellucida resulting in embryonic death. However, as the embryo developes and ages, $8 \mathrm{dpc}$ and beyond, it becomes more resistant to perturbation and thus is more tolerant. During the time of PG-PS challenge in our experiment, the embryo, 5-6 dpc, would be vulnerable and be targeted by proinflammatory cytokines and immune cells that may identify it as a possible pathogen and destroy it.

3. An early disruption in the uterine environment may not immediately lead to embryonic loss, or target the embryo specifically, however could cause problems during implantation or maternal recognition of pregnancy. The series of events from fertilization to maternal recognition of pregnancy require complexed coordination amongst a multitude of factors, it is rational to assume that any disturbance within this system could cause either the embryo or the uterine envirionment to be unprepared to accept one another. This lack of tolerance on the maternal side would disallow the embryo to implant, thereby no recognition of pregnancy would be initiated and ultimately pregnancy would be terminated.

There is no doubt that the early embro is vulnerable to any disturbances within the environment in which it lives. An immune response, via bacterial 
infections, would be capable of responding to a conceptus at this time, 5-6 dpc, as a foreign pathogen and destroy it. Moreover, the embro itself may be able to survive an innate immune challenge, however the uterine environment itself be damaged due to a localized inflammatory response. Regardless of indirect or direct actions, bacterial infections, such as mastitis cost the agricultural industry approximately $\$ 2$ billion each year (Pyorala, 2002). It is imparitive that more research is carried out to better understand and characterize the detrimental effects that such bacterial infections not only have on the dam, but potentially on the fetus as well. By better understanding mechanism of actions scientists can work to implement proper management techniques to not only treat, but prevent bacterial related economic losses that producers can utilize to their fullest extent. 


\section{References}

Actor, Paul, Alfred Chow, Frank Dutko, and Mark McKinlay. "Chemotherapeutics" in Ullmann's Encyclopedia of Industrial Chemistry New York: Wiley-VCH. 2002.

Adams, N.R. "Morphogenic Change in the Cervix of the Ewe after Prolonged Exposure to Estradiol-17ß.” Journal of Reproduction and Fertility 76 (1986): 727-733.

Aderem, Alan, and Kelly D. Smith. "A Systems Approach to Dissecting Immunity and Inflammation." Seminars in Immunology 16 (2004): 55-67.

Aggarwal, and Matarajan. "Review: Tumor Necrosis Factor:Developments During the Last Decade." Eur. Cytokine Netw. 7.2 (1996): 93-124.

Aggarwal, R, A Loganath, A C. Roy, Y C. Wong, and S C. Ng. "Effect of T-Helper 1 Cytokines on Secretion of T-Helper 2 Cytokines by Term Trophoblast Cells in Culture." Gynecological Endocrinology 14 (2000): 305-310.

Akira, S. "Toll Receptor Families: Structure and Function." Editorial. Seminars in Immunology Feb/Mar. 2004: 1-2.

Allen, C.A., and D.P.L. Green. "The Mammalian Acrosome Reaction: Gateway to Sperm Fusion with the Oocyte?" BioEssays 19 (1997): 241-247.

Almeida, E.A.C., A. Huovila, A.E. Sutherland, L.E. Stephens, P.G. Calarco, L.M. Shaw, A.M. Sonnenberg., P. Primakoff, D.G. Myles, and J.M. White. "Mouse Integrin Alpha-6ß1 Functions as a Sperm Receptor.” Cell 81 (1995): 1095-1104.

Amilla, M., V. Ramiya, J. Norimine, and H.A. Lewin. "The Major Histocompatibility Complex of Ruminants.” Rev. Sci. Tech. Off. Int. Epiz. 17 (1998): 108-120. Arai, T. "Susceptibilities of Bacteria against Chemotherapeutics under Different Conditions." Keio Journal of Medicine 26 (1977): 31-42. 
Arredouani, Mohamed S., Ahmad Kasran, Jeroen A. Vanoirbeek, Frank G. Berger, Heinz Baumann, and Jan L. Ceuppens. "Haptoglobin Dampens Endotoxin-Induced Inflammatory Effects Both in Vitro and in Vivo." Immunology 114 (2005): 263271.

Baird, D.T., and A.S. McNeilly. "Gonadotrophic Control of Follicular Development and Function During the Estrous Cycle of the Ewe." Journal of Reproduction and Fertility Supplement 30 (1981): 119-133.

Barker, A., F.N. Schrick, M.J. Lewis, H.H. Dowlen, and S.P. Oliver. "Influence of Clinical Mastitis during Early Lactation on Reproductive Performance of Jersey Cows.” J Dairy Sci 81 (1998): 1285-1290.

Baumann, H. and J. Gauldie. Immunology Today 15 (1994): 74-80.

Bazer, F W. "Establishment of Pregnancy in Sheep and Pigs." Reproduction, Fertility and Development 1 (1989): 237-242.

Bazer, F. W. Endocrinology of Pregnancy. Totowa, New Jersey: Humana Press, 1998.

Bazer, F. W., and H. M. Johnson. "Type I Conceptus Interferons: Maternal Recognition of Pregnancy Signals and Potential Therapeutic Agents." American Journal of Reproductive Immunology 26 (1991): 19-22.

Bazer, F W., and N. L. First. "Pregnancy and Parturition." Journal of Animal Science 57.S2 (1983): 425-460.

Bazer, F. W., and W. W. Thatcher. "Theory of Maternal Recognition of Pregnancy in Swine Based on Estrogen Controlled Endocrine Versus Exocrine Secretion of Prostaglandin F2 Alpha by Uterine Endometrium." Prostaglandins 14 (1977): $397-400$. 
Bazer, F. W., J. L. Vallet, R. M. Roberts, D. C. Sharp, and W. W. Thatcher. "Role of Conceptus Secretory Products in Establishment of Pregnancy." Journal of Reproduction and Fertility 76 (1986): 841-850.

Bazer, F.W., T. E. Spencer, and T. L. Ott. "Placental Interferons." American Journal of Reproductive Immunology 35 (1996): 297-308.

Bazer, F. W., T. L. Ott, and T. E. Spencer. "Pregnancy Recognition in Rumminants, Pigs and Horses: Signals from the Trophoblast." Theriogenology 41 (1994): 79-94.

Benoit, A. M., and R. A. Dailey. "Catheterization of the Caudal Vena Cava Via the Lateral Saphenous Vein in the Ewe, Cow, and Gilt: an Alternative to UteroOvarian and Medial Coccygeal Vein Catheters." J. Anim. Sci. 69 (1991): 29712979.

Blatteis, C.M. “The Onset of Fever: New Insights into its Mechanism.” Progressive Brain Research 162 (2007): 3-14.

Boving, B. G. "Blastocyst-Uterine Relationships." Cold Spring Harbor Symp. Quant. Biol. 19 (1954): 9-28.

Burch, R. M., and C. W. Tiffany. "Tumor Necrosis Factor Causes Amplification of Arachidonic Acid Metabolism in Response to Interleukin 1, Bradykinin, and Other Agonists." Journal of Cell Physiology 141 (1989): 85-89.

Buxton, D, I E. Anderson, D Longbottom, M Livingstone, S Wattegedera, and G Entrican. "Ovine Chlamydial Abortion: Characterization of the Inflammatory Immune Response in Placental Tissues." Journal of Comparative Pathology 127 (2002): 133-141. 
Carroll, J. A., R. L. Matteri, C. J. Dyer, L.A. Beausang, and M. E. Zannelli. "Impact of Environmental Temperature on Response of Neonatal Pigs to an Endotoxin Challenge." American Journal of Veterinary Research 62 (2001): 561-566.

Cavaillon J.M., G. Duff. "Cytokines and the Cellular Mechanism of Inflammation" in The Cytokine Network and Immune Function Oxford: Oxford University Press. 1999.

Ceciliani, F., A. Giordano, and V. Spagnolo. "The Systemic Reaction during Inflammation: the Acute-Phase Proteins." Protein and Peptide Letters 9 (2002): 211-223.

Chappell, P. E., J. P. Lydon, O. M. Conneely, B.W. O’Malley, and J. E. Levine. "Endocrine Defects in Mice Carrying a Null Mutation for the Progesterone Receptor Gene." Endo 138 (1997): 4147-4152.

Chowdhury, P., S.H. Sacks, and N.S. Sheerin. "Toll-Like Receptors TLR2 and TLR4 Initiate Immune Response of the Renal Tubular Epithelium to Bacterial Products." Clin Exp Immunol 145: 346-356.

Chun, J., and A. Prince. "Activation of $\mathrm{Ca}+2$ Dependent Signaling by TLR-2." J. of Immun. 177 (2006): 1330-1337.

Cid, M.C., D.S. Grnat, G.S. Hoffman, R. Auerbach, A.S. Fauci, and H.K. Kleinman. Journal of Clinical Investigation 91 (1993): 977-985.

Daels, P F., G H. Stabenfeldt, J P. Hughes, K Odensvik, and H Kindahl. "Evaluation of Progesterone Deficiency as a Cause of Fetal Death in Mares with ExperimentallyInduced Endotoxemia." American Journal for Veterinary Research 52 (1991): 282-288. 
De, M, T R. Sanford, and G W. Wood. "Interleukin-1, Interleukin-6, and Tumor Necrosis Factor Alpha are Produced in the Mouse Uterus During the Estrous Cycle and are Induced by Estrogen and Progesterone." Developmental Biology 151 (1992): 297-305.

Dean, J. "Biology of Mammalian Fertilization: Role of the Zona Pellucida.” Journal of Clinical Investigation 89 (1992): 1055-1059.

Denker, H. W. "Structural Dynamics and Function of Early Embryonic Coats." Cells, Tissues, Organs 166 (2000): 180-207.

Draincourt, M.A., A. Gougeon, A. Royere, and C. Thibault. Reproduction in Mammals and Man. Paris: Ellipses, 1993.

Dunbar, Bonnie S., S V. Prasad, and T M. Timmons. A Comparative Overview of Mammalian Fertilization. New York: Plenum Press, 1991. 97-113.

Dutt, R H. "Critical Period for Early Embryo Mortality in Ewes Exposed to High Ambient Temperature." Journal of Animal Science (1963): 713-719.

Eaglesome, M.D., W.C. Hare, and E.L. Singh. "Embryo Transfer: a Discussion on Its Potential for Infectious Disease Control Based on a Review of Studies on Infection of Gametes and Early Embryos by Various Agents." Can. Vet. J. 21 (1980): 106-112.

Eaton, J.W., P. Brandt, J.R. Mahoney, and J.T. Lee Jr. "Haptoglobin: a Natural Bacteriostat." Science. 1982 Feb 5; 215(4533): 691-3.

Edwards, R. G., B. D. Bavister, and P. C. Steptoe. "Early Stages of Fertilization in Vitro of Human Oocytes Matured in Vitro." Nature 221 (1969): 632-635. 
Elsasser, T.H., Blum, and S. Kahl. "Characterization of Calves Exhibiting a Novel Inheritable TNF-Alpha Hypersensitiveness to Endotoxin: Associations with Increased Pathophysiological Complications." J. Appl. Physiol. 98 (2005): 20452055.

Entrician, E.A. and J. Wheelhouse. "Immunity in the Female Sheep Reproductive Tract." Vet. Res. 37 (2006): 295-309.

Erlebacher, Adrian, Dorothy Zhang, Albert F. Parlow, and Laurie H. Glimcher. "Ovarian Insufficiency and Early Pregnancy Loss Induced by Activation of the Innate Immune System." J Clin Invest 114 (2004): 39-48.

Fahey, John V., Todd M. Schaefer, and Charles R. Wira. "Sex Hormone Modulation of Human Uterine Epithelial Cell Immune Responses." Integrative and Comparative Biology 46 (2006): 1082-1087.

Fan, Hongkuan, Basilia Zingerelli, Octavia M. Peck, Giuseppe Teti, George E. Tempel, Perry V. Halushka, and James A. Cook. "Lipopolysaccharide- and Gram Positive Bacteria-Induced Cellular Inflammatory Responses: Role of Heterotimeric G\&\#945; I Proteins." Am J Physiol Cell Physiol 289 (2005): c293-c301. Fleming, J.A., T.E. Spencer, S.H. Safe, and F.W. Bazer. "Estrogen Regulates Transcription of the Ovine Oxytocin Receptor Gene through GC-rich SP 1 Promoter Elements.” Endocrinology 147 (2006): 899-911.

Fleming, J.A., Y. Choi, G.A. Johnson, .E. Spencer, and F.W. Bazer. "Cloning the Ovine Estrogen Receptor-alpha Promoter and Functional Regulation by Ovine Interferon-tau." Endocrinology 142 (2001): 2879-2887. 
Fritz, Jorg H. "How TLR and NOD-like Receptors Contribute to Innate Immunity in Mammals.” Journal of Endotoxin Research 11.6 (2005): 390-394.

Gabay, and Kushner. "Acute-Phase Proteins and Other Systemic Responses to Inflammation. " New England Med. J. 340.6 (1999): 448-454.

Gendron, R L., F P. Nestel, W S. Lapp, and M G. Baines. "Lipopolysaccharide-Induced Fetal Resorption in Mice is Associated with the Intrauterine Production of Tumour Necrosis Factor-Alpha." J Reprod Fert 90 (1990): 395-402.

Gilbert. S.F. Developmental Biology $8^{\text {th }}$ ed. Sunderland: Sinauer Association Inc. 2006.

Girardin, S.E., I.G. Boneca, J. Viala, M. Chamaillard, A. Labigne, G. Thomas, D.J. Philpott, and P.J. Sansonetti. "NOD 2 is a General Sensor of Peptidoglycan through Muramyl Dipeptide (MDP) Detection.” J. Biol. Chem. 278 (2003): 88698872.

Glabe C.G., and V. D. Vacquier. "Egg Surface Glycoprotein Receptor for Sea Urchin Sperm Bindin.” Proceedings of the National Academy of Sciences of the United States of America 75 (1978): 881-885.

Goldsby, R.A., T.K. Kindt, B.A. Osborne, and J. Kuby. Immunology $5^{\text {th }}$ ed. New York: W.H. Freeman and Company. 2003.

Goodman, R. L., and E. K. Inskeep. "Neuroendocrine Control of the Ovarian Cycle of the Sheep." Knobil and Neill's Physiology of Reproduction. New York, NY. Elsevier, 2006. 2389-2444.

Greenblatt, J, R J. Boackle, and J H. Schwab. "Activation of the Alternate Complement Pathway by Peptidoglycan Form Streptococcal Cell Wall." Infect Immun 19 (1978): 296-303. 
Grigsby, Peta L., Jonathan J. Hirst, Jean-Pierre Scheerlinck, David J. Phillips, and Graham Jenkin. "Fetal Responses to Maternal and Intra-Amniotic Lipopolysaccharide Administration in Sheep." Biology of Reproduction 68 (2003): 1695-1702.

Gruys, E., M. J. M. Toussaint, N. Upragarin, A. M. Van Ederen, A. A. Adewuyi, D Candiani, T K A. Nguyyen, and J Sabeckiene (balciute). "Review: Acute Phase Reactants, Challenge in the Near Future of Animal Production and Veterinary Medicine." Journal of Zhejiang University SCIENCE 6B.10 (2005): 941-947.

Gruys, E., M. Obwolo, and M.J.M. Tousaint. "Diagnostic Significance of the Major Acute Phase Proteins in Veterinary Clinical Chemistry: a Review.” Veterinary Bulletin 64 (1994): 1019-1018.

Gupta, D., Y. Jin, and R. Dziarski. "Peptidoglycan Induces Transcription and Secretion of TNF-Alpha and Activation of Lyn, Extracellular Signal-Regulated Kinase, and Rsk Signal Transduction Proteins in Mouse Macrophages." J Immun 155 (1995): 2620-2630.

Gupta, D. "Molecular Steps of TNF Receptor-Mediated Apoptosis." Cur Molec Med. 1 (2001): 317-324.

Haddad, E. K., A. J. Duclos, W. S. Lapp, and M. G. Baines. "Early Embryo Loss is Associated with the Prior Expression of Macrophage Activation Markers in the Decidua." J Immun 158 (1197): 4886-4892.

Hansen, P J. "Exploitation of Genetic and Physiological Determinants of Embryonic Resistance to Elevated Temperature to Improve Embryonic Survival in Dairy Cattle During Heat Stress." Theriogenology - - in Press (2007): 1-8. 
Hansen, P J. "Regulation of Immune Cells in the Uterus during Pregnancy in Ruminants." J An Sci 85 (2007): e30-e31.

Hansen, P J. "To Be or Not to Be--- Determinants of Embryonic Survival Following Heat Shock." Theriogenology - - in Press (2007): 1-9.

Hansen, P J., P Soto, and R P. Natzke. "Mastitis and Fertility in Cattle - Possible Involvement of Inflammation or Immune Activation in Embryonic Mortality." Am J Reprod Immun 51 (2004): 294-301.

Hardy, K., and S. Spanos. "Review: Growth Factor Expression and Function in the Human and Mouse Preimplantation Embryo." J of Endo. 172 (2002): 221-236.

Hastings, R.A., A.C. Enders, and S. Schlafke. "Permeability of the Zona Pellucida to Protein Tracers." Bio. of Reprod. 7 (1972): 288-296.

Hawlishch, H.,and J. Kohl. "Complement and TLR: Key Regulators of Adaptive Immune Responses.” Molec Immun 43.1-2 (2006): 13-21. Review.

Heinrich, Peter C., Jose V. Castell and Tilo Andus. "Interleukin-6 and the Acute Phase Response.” Journal of Biochemistry 265 (1990): 621-636.

Holaskova, I, G S. Lewis, M Elliott, K P. Blemings, and R A. Dailey. "Effects of Peptidoglycan-Polysaccharide Complex on Reproductive Efficiency in Sheep." Am J Reprod Immun 52 (2004): 197-203.

Hoyer, P.B. "Regulation of Luteal regression: The Ewe as a Model." J Soc Gyn Invest 5 (1998): 49-57.

Hoyer, P.B., and G.D. Niswender. "The Regulation of Steroidogenesis is Different in the Two Types of Ovine Luteal Cells.” Canadian Journal of Physiology and Pharmacology 63 (1985): 240-248. 
Huber, B., O. Deinsky, R.K. Gershon, and H. Cantor. “Cell-mediated Immunity: Delayed-type Hypersensitivity and Cytotoxic Rersponses are Mediated by Different T-cell Subclasses.” J Exp Med 143 (1976): 1534-1539.

Huet-Hudson, Y M., G K. Andrews, and S K. Dey. "Cell-Type Specific Localization of C-Myc Protein in the Mouse Uterus: Modulation of Steroid Hormones and Analysis of the Preimplantation Period." Endocrinology 125 (1989): 1683-1690.

Hunt, J., H. Chen, and L. Miller. "Tumor Necrosis Factors: Pivitol Components of Pregnancy." Bio. of Reprod. 54 (1996): 554-562.

Jacobsen, S., P.H. Andersen, T. Toelboell, and P.M.H. Heegaard. "Dose Dependency and Individual variability of the Lipopolysaccharide Induced Bovine Acute Phase Protein Response.” J Dairy Sci 87 (2004): 3330-3339.

Janeway Jr, C. A., and R. Medzhitov. "Innate Immune Recognition.” Ann Rev Immun 20 (2002): 197-216.

Joyce, D., C. Albanese, J. Steer, M. Fu, B. Bouzahzah, and R.G. Pestell. “Targets of Glucocorticoid Action on TNF-alpha Release by Macrophages.” Cytokine Growth Factor Review 12 (2001): 73-90.

Kabaroff, L, H Boermans, and N A. Karrow. "Changes in Ovine Maternal Temperature, and Serum Corisol and Interleukin-6 Concentrations after Challenge with Escherichia Coli Lipopolysaccharide during Pregnancy and Early Lactation." J Ani Sci 84 (2006): 2083-2088.

Kabaroff, L. C., A. Rodriguez, M. Quinton, H. Boermans, and N. A. Karrow. "Assessment of the Ovine Acute Phase Response and Hepatic Gene Expression in 
Response to Escherichia Coli Endotoxin." Vet Immun Immunopath 113 (2006): 113-124.

Kahl, S, and T H. Elsasser. "Exogenous Testosterone Modulates Tumor Necrosis FactorAlpha and Acute Phase Protein Responses to Repeated Endotoxin Challenge in Steers." Dom Ani Endo (2005): 1-11.

Kasa-Vabu, J.Z., G.E. Dahl, N.P. Evans, L.A. Thrun, S.M. Moenter, V. Padmanabhan, and F.J. Karsh. "Progesterone Blocks the Estrodial-induced Gonadotrophin Discharge in the Ewe by Inhibiting the Surge of Gonadatropin Releasing Hormone.” Endocrinology 131 (1992): 208-212.

Guzeloglu-Kayisli, O., N. Mahutte, and A. Arici. "Uterine Chemokines in Reproductive Physiology and Pathology." AJRI 47 (2002): 213-221.

Kengatharan, K. M., S. De Kimpe, C. Robson, S. J. Foster, and C. Thiemermann. "Mechanism of Gram-Positive Shock: Identification of Peptidoglycan and Lipoteichoic Acid Moieties Essential in the Induction of Nitric Oxide Synthase, Shock, and Multiple Organ Failure." J Exp Med 188 (1998): 305-315.

Kenison, D.C., T.H. Elsasser, andR. Fayer. "Radioimmunoassay for Bovine TNF: Concentrations and Circulating Molecular Forms in Bovine Plasma." $\underline{\text { J. of }}$ Immunoassay 11 (1990): 177-198.

Kishimoto, T., S. Akira, and T. Taga. Science 258 (1992): 593-597.

Kluger, M.J., W. Kozak, L.R. Leon, D. Soszynski, and G.A. Conn. "Cytokines and Fever." Neurommunomodulation 2 (1995): 216-223. 
Knights, M., T. Hoehn, D. Marsh, P. Lewis, J. Pate, A. Dixon, and E. K. Inskeep.

"Reproductive Management in the Ewe Flock by Induction or Synchronization of Estrus." W.V. Agricultural and Forestry Experiment Station Bulletin 726 (2003).

Kohmura, Y., T. Kirikae, F. Kirikae, M. Nakano, and I. Sato. "Lipopolysaccharide (LPS)Induced Intra-Uterine Fetal Death (IUFD) in mice is Principally Due to Maternal Cause But Not Fetal Sensitivity to LPS." Micro Immun 44.11 (2000): 897-904.

Koj, A. Biochem. Biophys. Acta. 1317 (1996): 84-94.

Krishna, A., K. Beesley, and P.F Terranova. "Histamine, Mast Cells and Ovarian Function.” J Endo 120 (1989): 363-371.

Kushner, I. Perspec Bio Med 36 (1993): 611-622.

Kuwano, T., S. Nakao, H. Yamamoto, M. Tsuneyashi, T. Yamamoto, M. Kuwano, and M. Ono. "Cyclooxygenase 2 is a Key Enzyme for Inflammatory CytokineInduced Angiogenesis." FASEB J 18 (2004): 300-310.

Land, R.B., D.T. Baird, and R.J. Scaramuzzi. "Dynamic Studies of PGF-2 $\alpha$ in the Uteroovarian Circulation of the Sheep.” J Reprod Fert 47 (976): 209-214.

Li, X., B.U. Bradford, F. Dalldorf, S.M. Goyert, S.A. Stimpson, R.G. Thurman, and S.S. Makarov. "CD14 Mediates the Innate Immune Responses to Arthitopathogenic Peptidoglycan-Polysaccharide Complexes of Gram-Positive Bacterial Cell Walls." Arthritis Research and Theory 6 (2003): r273-r281.

Lindhorst, E, D Young, W Bagshaw, M Hyland, and R Kisilevsky. "Acute Inflammation, Acute Phase Serum Amyloid A and Cholesterol Metabolism in the Mouse." BBA/ Pro Struc Molec Enzym 12 (1997): 143-154. 
Loureiro, B., A.M. Brad, and P.J. Hansen. "Heat Shock and Tumor Necrosis FactorAlpha Induce Apoptosis in Bovine Preimplantation Embryos Through a Caspase9-Dependent Mechanism." Reproduction 133 (2007): 1129-1137.

Lucy, M.C., S. McDougall, and D.P. Nation. "The Use of Hormonal Treatments to Improve the Reproductive Performance of Lactating Dairy Cows in Feedlot or Pasture-based Management Systems.” Ani Reprod Sci 82-83 (2004): 495-512.

Lumney, J.K., M.J. Paape, and D.D. Bannerman. "Immunity: Acquired" in Encyclopedia of Animal Science New York: Marcel Dekker. 2004.

Marrack, P. and J.W. Kappler. "How the Immune System Recognizes the Body.” $\underline{\text { Sci. }}$ Am. 269 (1993): 81-89.

McClure, L, A E. O'conner, S Hayward, G Jenkin, D W. Walker, and D J. Phillips. "Effects of Age and Pregnancy on the Circulation of Activin Response in Sheep to Acute Inflammatory Challenge by Lipopolysaccharide." J Endo 185 (2005): 139-149.

McCormack, C.C., A.H. Hobson, S. Doyle, J. Jackson, C. Kilty, and A.S. Whitehead. "Generation of Soluble Recombinant Human Acute Phase Serum Amyloid A2 (aSAA-2_ Protein and Its Use in Development of an a-SAA Specific ELISA." 즈 Immun Meth 198 (1996): 101-110.

McCracken, J A. "Prostaglandin F2 Alpha Identified as a Luteolytic Hormone in Sheep." Nat New Bio 238 (1972): 129-134.

McCracken, J A., E E. Custer, and J C. Lamsa. "Luteolysis: a Neuroendocrine-Mediated Event." Physiology Review 79 (1999): 263-323. 
McGuire, W.J., J.L. Juengel, and G.D. Niswender. "Protein Kinase C Second Messenger System Mediates the Antisteroidogenic Effects of PGF-2 $\alpha$ in the Ovine Corpus Luteum in vivo." Bio Repro 51 (1994): 800-806.

McWaters, M, L Hurst, P J. Chapman, R A. Collins, P R. Wood, and J P. Scheerlinck. "Characterisation of Monoclonal Antibodies to Ovine Interleukin-6 and the Development of a Sensitive Capture ELISA." Vet Immun Immunopath 73 (2000): $155-165$.

Meikle, A., C. Tasende, C. Sosa, and E.G. Garofalo. "The Role of Sex Steroid Receptors in SheepFemale Reproductive Physiology.” Reprod Fert Devel 16 (2004): 385394.

Moore, D.A., W. Overton, R.C. Chebel, M.L. Truscott, and R.H. Bon Durant. "Evaluation of Factors That Affect Embryonic Loss in Dairy Cattle." J Am Vet Med Assoc 226 (2005): 1112-1118.

Morley, J.J., and I. Kushner. Ann NY Acad Sci 389 (1982): 406-418.

Morris, D., M. Diskin, and J. Sreenan. "Investigating Early Embryo Loss in Cattle." The Irish Scientist Yearbook (2002). 1 June 2007 $<$ http://www.irishscientist.ie/2002/contents.asp?contentxml=02p44.xml\&contentxsl=is02 $>$.

Morris, Peter, Center for Disease Control. "Severe Sepsis." ICD-9-CM Coordination and Maintenance Committee Meeting 2001

Mosmann, T R., and R I. Coffman. "Th1 and Th2 Cells: Different Patterns of Lymphokine Secretion Lead to Different Functional Properties." Annual Review in Immunology 7 (1989): 145-188. 
Mueller, T., and D.K. Podolsky. "Nucleotide-binding-oligomerization Domain Proteins and TLR: Sensors of the Inflammatory Bowel Diseases' Microbial Environment.” Cur Opin. Gastroenterol. 21 (2005): 419-425.

Muller-Eberhard, H.J. “The Membrane Attack Complex of Complement.” Ann Rev Immun 4 (1986): 503-528.

Murdoch, W.J., D.C. Colgin, and J.A. Ellis. "Role of TNF-Alpha in the Ovulatory Mechanism of Ewes." J. Anim. Sci. 75 (1997): 1601-1605.

Murdoch, W J., T A. Peterson, E A. Van Kirk, D L. Kirk, and E K. Inskeep. "Interactive Roles of Progesterone, Prostaglandins, and Collagenase in the Ovulatory Mechanism of the Ewe." Bio Reprod 35 (1986): 1187-1194.

Murdoch, W. J., and S.A. Lund. "Prostaglandin-Independent Anovulatory Mechanism of Indomethacin Action: Inhibition of Tumor Necrosis Factor Alpha-Induced Sheep Ovarian Cell Apoptosis." Bio Reprod 61 (1999): 1655-1659.

Murillo, L.S., S.A. Morre, and A.S. Pena. "TLR and NOD/CARD Proteins: Pattern Recognition Receptors are Key Elements in the Regulation of Immune Response.” Drugs Today (b.a.r.c.) 39 (2003): 415-38. Review.

Nakayama, Sonoda, Urano, Yamada, and Okuda. "Monitoring Both SAA and CReactive Protein as Inflammatory Markers in Infectious Diseases." Clin. Chem. 39 (1993): 293-297.

Nasar, A., A. Rahman, K.J. Snibson, C.S. Lee, and E. N. T. Meeusen. "Effects of Implantation and Early Prenancy on the Expression of Cytokines and Vascular Surface Molecules in the Sheep Endometrium." J Reprod Immun 64 (2004): 4558. 
Neumann, I D. "Alterations in Behavioural and Neuroendocrine Stress Coping Strategies in Pregnant, Parturient and Lactating Rats." Prog Brain Res 133 (2001): 143151.

Neuvians, T.P., D. Schams, B. Berisha, and M.W. Pfaffl. "Involvement of ProInflammatory Cytokines, Mediators of Inflammation, and bfGF in PGF-2 $\alpha$ induced Luteolysis in Bovine CL.” Bio Reprod 70 (2004): 473-480.

Nielson, C.H., E.M. Fischer, and R.G.Q. Leslie. "The Role of Complement in the Acquired Immune Response.” Immunology 100 (2000): 4-12.

O'conner, M., and C. Dechow. "Minimize the Adverse Affect of the Dog Days of Summer on Reproduction." Penn State Dairy Digest 109 (2006): 2-3.

Okuda, K., and R. Sakumoto. "Review- - Regulation of Uterine Function by Cytokines in Cows: Possible Actions of Tumor Necrosis Factor-Alpha, Interleukin-1 Alpha, and Interferon-Tau." An Sci J 77 (2006): 266-274.

Papanicolau, D., R.L. Wilder, S.C. Manlagas, and .P. Chrousos. "The Pathophysiologic Roles of Interleukin-6 in Human Disease.” Ann Inter Med 128 (1998): 127-137

Paria, B.C., H. Song, and S. K. Dey. "Implantation: Molecular Basis of Embryo-Uterine Dialogue." Inter J Develop Bio 45 (2001): 597-605.

Pasare, C., and R. Medzhitov. "TLR and Acquired Immunity.” Sem Immun 16 (2004): 23-26.

Pate, J.L. "Involvment of Immune Cells in Regulation of Ovarian Function.” J Reprod Fert Sup 49 (1995): 365-377.

Pechlaner, Ch. "Plasminogen Activators in Inflammatin and Sepsis." Acta. Med. Austriaca 29 (2002): 80-88. 
Pineau, I., and S. Lacroix. "Proinflammatory Cytokine Synthesis in the Injured Mouse Spinal Cord: Multiphasic Expression Pattern and Identification of the Cell Types Involved." J Comp Neur 500 (2007): 267-285.

Pitzel,L., H. Jarry, and W. Wuttke. "Effects and Interactions of PGF- $2 \alpha$, Oxytocin, and Cytokines on Steroidogenesis of Porcine CL.” Endocrinology 132 (1993): 751756.

Pober, J.S. "Endothelial Activation: Intracellular Signaling Pathways.” Arthritis Reasearch 4.S3 (2002): s109-s116.

Quayle, A. J. "The Innate and Early Immune Response to Pathogen Challenge in the Female Genital Tract and the Pivotal Role of Epithelial Cells." J. of Reprod. Immun. 57 (2002): 61-79.

Raghupathy, R. "Th1-Type Immunity is Incompatible with Successful Pregnancy." Immunology Today 18 (1997): 478-482.

Riesenfeld-Orn, I, S Wolpe, J F. Garcia-Bustos, M K. Hoffmann, and E Tuomanen. "Production of Interleukin-1 But Not Tumor Necrosis Factor by Human Monocytes Stimulated with Pneumococcal Cell Surface Components." Infect Imm 57.7 (1989): 1890-1893.

Roberts, R.M., F.W. Bazar. “The Functions of Uterine Secretions.” J Reprod Fert 82 (1988): 875-892.

Roberts, R.M., S. Xie, N. Mathialagan. "Maternal Recognition of Pregnancy.” $\underline{B i o}$ Reprod 54 (1996): 294-302. 
Robertson, S.A, A.S. Care, and R.J. Skinner. "IL-10 Regulates Inflammatory Cytokine Synthesis to Protect Against Lipopolysaccharide-Induced Abortion and Fetal Growth Restriction in Mice." Bio. of Reprod. 76 (2007): 738-748.

Rogers, G.M. "Tumor Necrosis Factor-Alpha Production Induced by PeptidoglycanPolysaccharide in Early Pregnant Ewes." Thesis West Virginia Univ., 2006.

Royet, J., and R.Dziarski. "Peptidoglycan Recognition Proteins: Pleiotropic Sensors and Effectors of Antimicrobial Defenses." Nature 5 (2007): 264-277.

Satterfield, M.C., F.W. Bazer, and T.E. Spencer. "Progesterone Regulation of Preimplantation Conceptus Growth and Galectin 15 (LGALS15) in the Ovine Uterus." Bio. of Reprod. 75 (2006): 289-296.

Schleifer, K H., and O Kandler. "Peptidoglycan Types of Bacterial Cell Walls and Their Taxonomic Implications." Bacterio Rev 36 (1972): 407-477.

Schwandner, R., R. Dziarski, H. Wesche, M. Rothe, and C.J. Kirchning. "PG- and Lipotheichoic Acid-induced Cell Activation is Mediated by TR-2.” J Bio. Chem. 274.25 (1999): 17406-17409.

Scott, C.J., A.J. Tilbrook, J.A. Rawson, and I.J. Clarke. “Gonadal Steroid Receptors in the Regulation of GnRH Secretion in Farm Animals.” An Reprod Sci60-61 (2000): 313-326.

Sehagiri, P.B., D.I. McKenzie, B.D. Bavister, JL. Williamson, and JM. Aiken. "Golden Hamster Embryonic Genome Activation Occurs at the Two-cell Stage: Correlation with Major Developmental Changes.” Molec Reprod Develop 32 (1992): 229-235. 
Senger, P.L. Pathways to Pregnancy and Parturition. $2^{\text {nd }}$ ed. Pullman, Washington: Current Concepts Inc. 2003.

Schlafer, D.H., T.H. Elsasser, B. Yuh, G.L. Foley, D. Sadowsky, and P.W. Nathanielsz. "Effect of Salmonella Endotoxin Administered to the Pregnant Sheep At 133-142 Day Gestation on Fetal Oxygenastion, Maternal and Fetal Adrenocorticotropic Hormone and Cortisol, and Maternal Plasma TNF-Alpha Concentration." $\underline{B i o}$ Reprod 50 (1994): 1297-1302.

Shahani, S.K., C. Moniz, S. Chitlange, and P. Meherji. "Early Pregnancy Facotr (epf) as a Marker for the Diagnosis of Sub-clinical Embryonic Loss.” Exp Clin Endo 99 (1992): 123-128.

Sheffel, C E., Pratt, B R. Ferrel, and E. K. Inskeep. "I. Induced Corpora Lutea in the Postpartum Beef Cow. II. Effects of Treatment with Progesterone and Gonadotropins." Journal of Animal Science 54 (1982): 830-836.

Silver, R.M., W S. Lohner, R.A. Daynes, M.D. Mitchell, and D W. Branch. "Lipopolysaccharide-Induced Fetal Death: the Role of Tumor-Necrosis Factor Alpha." Bio Reprod 50 (1994): 1108-1112.

Sinowatz, F., E. Topfer-Petersen, S. Kolle, and G. Palma. "Review: Functional Morphology of the Zona Pellucida." Anat Hist Emb 30 (2001): 257-263.

Skarzynski, D.J., M.M. Bah, and K.M. Deptula. "Roles of TNF-Alpha of the Estrous Cycle in Cattle: an in Vivo Study." Bio Reprod. 69 (2003): 1907-1913. Soto, P, R P. Natzke, and P J. Hansen. "Identification of Possible Mediators of Embryonic Mortaliity Caused by Mastitis: Actions of Lipopolysaccharide, Prostaglandin F2 Alpha, and the Nitirc Oxide Generator, Sodium Nitroprusside 
Dihydrate, on Oocyte Maturation and Embryonic Development in Cattl." Am J Reprod Immun 50 (2003): 263-272.

Spencer, T.E. G.A. Johnson, F.W. Bazer, and R.C. Burghardt. "Implantation Mechanisms: Insights from Sheep." Reprod. 128 (2004): 657-668.

Steel,D.M., and A.S. Whitehead. Immunology Today 15 (1994): 81-88.

Stevenson, J.S. "Reproductive Management of Dairy Cows in High Milk-producing Herds.” J Dairy Sci 84 (2001): Supplement

Stewart, A., E. K. Inskeep, E.C. Townsend, and R. A. Dailey. "Effects of Gram-Positive Bacterial Pathogens in Ewes: Peptidoglycan as a Potential Mediator of Interuption of Early Pregnancy." Reprod. 125 (2003): 295-299.

Takeda, K., and S. Akira, “TLR Signaling Pathways.” Sem Immun 16 (2004): 3-9.

Takeda, K., and S. Akira. “Toll-like Receptors in Innate Immunity.” Intern Immun 17 (2005): 1-14.

Takenaka, I., M. Ogata, K. Koga, T. Matsumoto and A. Shigematsu. "Ketamine Suppresses Endotoxin-induced Tumor Necrosis Factor-Alpha Production in Mice.” Anesthesiology 80 (1994): 402-408.

Thron, C F., Z Y. Lu, and A S. Whitehead. "Regulation of the Human Acute Phase Serum Amyloid a Genes by Tumour Necrosis Factor-Alpha, Interleukin-6, and Glucocorticoids in Hepatic and Epithelial Cell Lines." Scand J Immun 59 (2004): $152-158$.

Tizard, I.R. Veterinary Immunology: an Introduction. 7th ed. Philadelphia: Saunders, 2004. 
Todar, K. Mechanisms of Bacterial Pathogenicity: Bacterial Defense Against the Host Immune Responses Madison: University of Wisconsin-Madison Press. 2002. Tomlinson, S. “Complement Defense Mechanisms.” Current Opin. Immunol. 5 (1993): 83-89.

Turner, K. and R.W. Horobin. "Permeability of the Mouse Zona Pellucida: a Structural Staining-Correlation Model Using Coloured Probes." J Reprod. Fert. 111 (1997): 259-265.

Uhlar, C.M. and A.S. Whitehead. "SAA, the Major Vertebrate Acute-Phase Reactant." Euro J Bioch 265 (1999): 501-523.

Vagnoni, K., and R. Magness. "Estrogen and Lipopolysaccharide Stimulation of Prostacyclin Production and the Levels of Cyclooxygenase and NOS in Ovine Uterine Arteries." Bio Reprod. 59 (1998): 1008-1015.

Van Deventer, S.J., H.R. Buller, J.W. en Cate, L.A. Aarden, C.E Hack, and A. Sturk. "Experimental Endotoxemia in Humans: Analysis of Cytokine Release and Coagulation, Fibrinolytic, and Complement Pathways.” Blood 76 (1990): 25202526.

Vaughan, J.E., and S.W. Walsh. "Neutrophils from Pregnant Women Produce Thromboxane and TNF-Alpha in Response to Linoleic Acid and Oxidative Stress." Am J Ob Gyn 193 (2005): 830-835.

Wallis, S. Infrared Thermography for Screening and Early Detection of Mastitis Infections in Working Dairy Herds. InfraMation 2005 Proceedings, 1 June 2005, University of California. Humbolt, 2005. 
Wang, J.H., M. Wang, J.L. Ma, L.G. Jiao, X.Y. Zhou, and J.E. Lindberg. "The Influence of Intramammary Lipopolysaccharide Infusion on Serum Ca, P, Vitamin D, Cytokines, and Cortisol Concentrations in Lactating Sows." J Vet Med. A 53 (2006): 113-118.

Wang, X. "Conception, Early Pregnancy Loss, and Time to Clinical Pregnancy: A population-based Prospective Study.” Fert Ster 79 (2003): 577-584.

Wassarman, P. M. Elements of Mammalian Fertilization: Practical Applications vol. 2. Colorado: CRC Press. 1990.

Wijayagunawardane, M.P., C. Gabler, G. Killian,and A. Miyamoto. "TNF-Alpha in the Bovine Oviduct during the Estrous Cycle: Messenger RNA Expression and Effect on Secretion of Prostaglandins, ET-1 and Ang II." Bio Reprod. 69 (2003): 13411346.

Wijayagunawardane, M.P. and A. Miyamoto. "TNF- $\alpha$ System in the Bovine Oviduct: a Possible Mechanism for Embryo Transport.” J Reprod Develop 50 (2004).

Williams, K I., K. E. H. El-Tahir, and E. Marcinkiewicz. "Dual Actions of Prostacyclin (PGI2) on the Rat Pregnant Uterus." Prostaglandins 17 (1979): 667-672.

Wilson, J.W., M.J. Schurr, C.L. LeBlanc, R. Ramamurthy, K.L. Buchanan, and C.A. Nickerson. "Mechanisms of Bacterial Pathogenicity.” Postgrad Med J 78 (2002): 216-224.

Wilson, T. C., C.J. Bachurski, M. Ikegami, and A.H. Jobe. "Pulmonary and Systemic Induction of SAA3 After Ventilation and Endotoxin in Preterm Lambs." Ped Res 58 (2006): 1204-1209. 
Wimsatt, W A. "New Histological Observations on the Placenta of the Sheep." Am J Anat 87 (1950): 391-436.

Winter, P., M. Miny, K. Fuchs, and W. Baumgartner. "The Potential of Measuring Serum Amyloid A in Individual Ewe Milk and in Farm Bulk Milk for Monitoring Udder Health on Sheep Dairy Farms." Res Vet Sci 81 (2006): 321-326.

Wira, C.R., J.V. Fahey, C.L. Sentman, P.A. Pioli, and L.Shen. "Innate and Adaptive Immunity in the Female Tract: Cellular Responses and Interactions.” Immun Rev 206 (2005): 306-335.

Wu, J.T., H. Wei, J. Zhang, and Z. Tian. "Increased Uterine NK-Derived IFN-Gamma and TNF-Alpha in C57BL/6J Mice during Early Gestation." Cell and Molec. Immun. 3.2 (2006): 131-137.

Wu, J. T., and R. K. Meyer. "Bacterium-Like Particles in Delayed Implanting Rat Blastocyst." J. Reprod. Fert. 28 (1972): 105-107.

Wu, W. X., X.H. Ma, and P.W. Nathanielsz. "Changes in Prostacyclin Synthase in Pregnant Sheep Myometrium, Endometrium, and Placenta At Spontaneous Term Labor and Regulation by Estogen and Progensterone." Am. J of Obstetrics and Gyne 180 (99): 744-749.

Xaus, J., M. Comalada, A.F. Valledor, J. Lloberas, F. Lopez-Soriano, J.M. Argiles, C. Bogdan, and A. Celada. "LPS Induces Apoptosis in Macrophages Mostly Through the Autocrine Productin of TNF-Alpha." Blood 95 (2000): 3823-3831. Yanagimachi. R. "Mammalian Fertilization" in Physiology of Reproduction $2^{\text {nd }}$ ed. Vol 1 New York: Raven Press. 1996. 